\title{
Biological control of aflatoxins in Africa: current status and potential challenges in the face of climate change
}

\author{
R. Bandyopadhyay ${ }^{1 "}$, A. Ortega-Beltran ${ }^{1}$, A. Akande ${ }^{2}$, C. Mutegi ${ }^{3}$, J. Atehnkeng ${ }^{4}$, L. Kaptoge ${ }^{1}$, A.L. Senghor ${ }^{5}$, B.N. \\ Adhikari $^{6}$, and P.J. Cotty ${ }^{6}$ \\ ${ }^{1}$ International Institute of Tropical Agriculture (IITA), PMB 5320, Oyo Road, 200001 Ibadan, Nigeria; ${ }^{2}$ IITA, PMB 82, \\ Garki GPO, Kubwa, Abuja, Nigeria; ${ }^{3}$ IITA, ILRI campus, P.O. Box 30772-00100, Nairobi, Kenya; ${ }^{4}$ IITA, Chitedze Research \\ Station, Off Mchinji Road, P.O. Box 30258, Lilongwe 3, Malawi; ${ }^{5}$ La Direction de la Protection des Végétaux (DPV), Km 15, \\ Route de Rufisque, en face Forail, BP 20054, Thiaroye-Dakar, Senegal; ${ }^{6}$ USDA-ARS, School of Plant Sciences, University \\ of Arizona, P.O. Box 210036, Tucson, AZ 85721-0036, USA; r.bandyopadhyay@cgiar.org
}

Received: 22 August 2016 / Accepted: 21 September 2016

(๑) 2016 Wageningen Academic Publishers

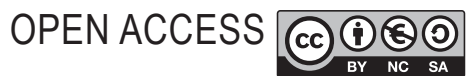

REVIEW ARTICLE

\begin{abstract}
Aflatoxin contamination of crops is frequent in warm regions across the globe, including large areas in sub-Saharan Africa. Crop contamination with these dangerous toxins transcends health, food security, and trade sectors. It cuts across the value chain, affecting farmers, traders, markets, and finally consumers. Diverse fungi within Aspergillus section Flavi contaminate crops with aflatoxins. Within these Aspergillus communities, several genotypes are not capable of producing aflatoxins (atoxigenic). Carefully selected atoxigenic genotypes in biological control (biocontrol) formulations efficiently reduce aflatoxin contamination of crops when applied prior to flowering in the field. This safe and environmentally friendly, effective technology was pioneered in the US, where well over a million acres of susceptible crops are treated annually. The technology has been improved for use in sub-Saharan Africa, where efforts are under way to develop biocontrol products, under the trade name Aflasafe, for 11 African nations. The number of participating nations is expected to increase. In parallel, state of the art technology has been developed for large-scale inexpensive manufacture of Aflasafe products under the conditions present in many African nations. Results to date indicate that all Aflasafe products, registered and under experimental use, reduce aflatoxin concentrations in treated crops by $>80 \%$ in comparison to untreated crops in both field and storage conditions. Benefits of aflatoxin biocontrol technologies are discussed along with potential challenges, including climate change, likely to be faced during the scaling-up of Aflasafe products. Lastly, we respond to several apprehensions expressed in the literature about the use of atoxigenic genotypes in biocontrol formulations. These responses relate to the following apprehensions: sorghum as carrier, distribution costs, aflatoxin-conscious markets, efficacy during drought, post-harvest benefits, risk of allergies and/or aspergillosis, influence of Aflasafe on other mycotoxins and on soil microenvironment, dynamics of Aspergillus genotypes, and recombination between atoxigenic and toxigenic genotypes in natural conditions.
\end{abstract}

Keywords: atoxigenic, maize, groundnut, Aflasafe, commercialisation

\section{Introduction}

Aflatoxins are highly toxic and carcinogenic mycotoxins that frequently contaminate several crops including maize, chillies, cottonseed, groundnuts, and tree nuts in warm agricultural areas across the globe (CAST, 2003; Cotty et al., 1994; Williams et al., 2004). Several Aspergillus species possess the ability to produce aflatoxins although the major causal agent of contamination globally is Aspergillus flavus (Klich, 2007). There are four major aflatoxins: $B_{1}, B_{2}, G_{1}$, and $G_{2}$; aflatoxin $B_{1}$ is the most toxic and prevalent and is classified as a Group 1a carcinogen by the International Agency for Research on Cancer (IARC, 2002). Crop aflatoxin contamination is a complex process that starts in the field 
resulting from environmental and biological factors such as host susceptibility, heat and high-temperature stress, insect attack, and aflatoxin-producing potentials of fungal communities interacting in a given area (Mehl et al., 2012; Widstrom, 1979; Williams, 2006). Aflatoxin contamination may start or continue after harvest if crops are stored under conducive conditions for fungal proliferation and aflatoxin formation (Cotty and Mellon, 2006). Consumption of foods containing high aflatoxin concentrations can cause acute health effects, such as liver cirrhosis and death (CDC, 2004; Probst et al., 2007), while sub-lethal chronic exposure may cause cancer and is associated with stunting in children, immune system suppression, and impaired food conversion (Bhat et al., 2010; Chan-Hon-Tong et al., 2013; Liu and Wu, 2010). Crop aflatoxin contamination limits domestic, regional, and international trade.

Aflatoxins have received considerable research attention for obtaining a good understanding of the biology, epidemiology, and occurrence of aflatoxin-producing fungi as well as to develop effective disease management strategies to minimise negative impacts on health, trade, and income. In this paper, we briefly emphasise the importance of aflatoxins in Africa, review the various management options available for aflatoxin management, and then focus on an in-depth analysis of the development and use of biocontrol as a tool for aflatoxin mitigation in Africa. We also discuss biocontrol as a management tool in the context of climate change and respond to some potential issues about biocontrol raised in the literature.

\section{Aflatoxins in Africa}

Aflatoxin-producing fungi are ubiquitous throughout Africa (Wild et al., 2016). Several aflatoxin-producing species maintain an intimate association with diverse crops, particularly maize and groundnut, leading to aflatoxin formation in both fields and stores; maize and groundnut are key staples of millions throughout sub-Saharan Africa (Cardwell and Cotty, 2002; Gong et al., 2003; Hell et al., 2000; Probst et al., 2014; Shephard, 2008). The large majority of smallholder farmers consume their crops as home-grown foods without the possibility of monitoring for aflatoxin content. Aflatoxin concentrations in commodities offered in local and informal markets are often unknown because of the absence of aflatoxin monitoring mechanisms (Shephard, 2003 , 2008). The frequent occurrence of aflatoxins in crops and inadequate monitoring capacity leads to high human aflatoxin exposure. However, some aflatoxin-conscious market segments are beginning to emerge in sub-Saharan Africa.

The nation that has been most affected by aflatoxin contamination outbreaks is Kenya, where human deaths have been repeatedly reported since 1981 (Probst et al., 2007, 2012). Human fatalities in Kenya have been attributed to acute aflatoxicosis events that resulted after frequent ingestion of maize contaminated with large quantities of aflatoxins produced by highly toxigenic groups of fungi. Similar deaths were reported in neighbouring Tanzania during 2016 (http://allafrica.com/stories/201607290685. html). Although reported human deaths as a result of aflatoxicosis are rare outside of Kenya and Tanzania, the situation is nevertheless grim in other African nations (Wild et al., 2016). Sub-lethal, long-term exposure to aflatoxins is pervasive throughout African nations and this results in child stunting, liver cancer, and immune system suppression that is accompanied with increased susceptibility to diseases, reduced success of vaccination programs, underdevelopment of the population, and reduced life-expectancy (Bandyopadhyay et al., 2007; Hernandez-Vargas et al., 2015; Williams et al., 2004). Malnutrition, which is prevalent throughout Africa, limits the ability of the human body to contest the harmful effects of aflatoxins (Cotty et al., 2008). Even the unborn are exposed to aflatoxins and its associated burdens. Women may expose their unborn child to aflatoxins during pregnancy and through breastfeeding, if they consume aflatoxin contaminated foods (Gong et al., 2003; Lamplugh et al., 1988; Oluwafemi and Ibeh, 2011). Food insecurity frequently forces people to consume contaminated foods because no other food options are available. In addition, commodities rejected from premium markets are often processed and offered at low prices in informal markets and this results in overexposure because aflatoxins in such products become highly concentrated.

\section{Aflatoxin management}

The aflatoxin contamination process can be divided into two phases based on the maturity of the crop. During crop development, when the first phase occurs, the crop becomes vulnerable as a result of physiological stress due to hot, dry conditions and/or insect activity that predispose the crop to fungal infection and subsequent aflatoxin formation (Cotty, 2001). The second phase occurs after crop maturity when the crop is exposed to both high temperatures and high humidity, which are conducive to fungal infection and may result in an increase of aflatoxin accumulation (Cotty, 2001). The second phase may occur in the field and/or during storage. Effective, commercially acceptable management practices should be directed to both phases of contamination (Cotty et al., 2008).

Several technologies have been recommended for the reduction of crop aflatoxin accumulation and subsequent human and animal aflatoxin exposure. These include cultural practices, biological control (biocontrol) of aflatoxin-producing fungi, monitoring and crop destruction, grain drying, sorting, storage, post-harvest processing, and dietary interventions (Hell et al., 2000, 2003, 2008; Jaime-Garcia and Cotty, 2004; Jones, 1987; Lillehoj et al., 1980; Russell et al., 1976; Waliyar et al., 2015). However, 
most of these are resource-consuming (time, labour, and money), and even when following all the guidelines of those management practices aflatoxin contamination may still occur when slight environmental changes happen (Bandyopadhyay and Cotty, 2013; Cotty, 2001; Wilson and Payne, 1994). In addition, some of those technologies are out of reach for use in developing countries. For example, automated sorting of discoloured kernels, which may contain high aflatoxin concentrations, is a helpful aflatoxin management tool for highly profitable industries (Matumba et al., 2015; Pelletier and Reizner, 1992) but as of today, it is not a feasible option to either small industries or resourcepoor farmers. Manual sorting of discoloured kernels is performed by smallholder farmers who try to sell their healthy looking kernels at a higher price (Matacic, 2016), but often keep the sorted kernels for their own consumption because of lack of knowledge of the effects of aflatoxins or because of food scarcity. Industries that sort kernels often process discarded kernels into products that enter local and informal markets at a low price thereby increasing aflatoxin exposure of poor people who purchase the culled products. Some of the management strategies are either not ethically appropriate (e.g. sorting without disposal systems in place) or socially practical (e.g. dietary interventions without strong policy changes) or not available for use by farmers. For example, commercially acceptable aflatoxin resistant maize and groundnut cultivars are not available to farmers (Brown et al., 2013; Fountain et al., 2015). Nevertheless, several efforts are underway to improve some of the practices (e.g. grain drying, storage, and crop resistance) and implement them on a large scale to prevent post-harvest losses.

It is evident that some of the strategies mentioned above are not sufficient to reduce incidences and severities of aflatoxin contamination events throughout sub-Saharan Africa. Fortunately, an efficient method to prevent contamination during pre- and post-harvest phases of contamination and that is based on beneficial fungi successfully reduces aflatoxin accumulation of susceptible crops in a costeffective manner (Bandyopadhyay and Cotty, 2013; Wu and Khlangwiset, 2010).

\section{Aflatoxin management through beneficial fungi}

The most frequently identified causal agent of aflatoxin contamination, $A$. flavus, occurs in nature in complex communities that can be divided into two largely distinct groups, the L- and the S-morphotypes. The L-morphotype produces abundant conidia, few, large sclerotia, and variable levels of B-aflatoxins, while the S-morphotype produces numerous small sclerotia, scarce conidiation, and consistently high levels of B-aflatoxins (Cotty, 1989). Phylogenetic analyses have shown that there are many aflatoxin producers with the S-morphology that do not fall within the species A. flavus (Probst et al., 2012,
2014). These include the named species Aspergillus minisclerotigenes (Pildain et al., 2008). Across the globe, several of these phylogenetically divergent fungal lineages with S-morphology produce large concentrations of both B- and G-aflatoxins (Cotty and Cardwell, 1999; Diedhiou et al., 2011; Donner et al., 2009; Perrone et al., 2014; Pildain et al., 2008; Probst et al., 2012, 2014).

Aflatoxin-producing species, including A. flavus, can be subdivided into numerous vegetative compatibility groups (VCGs) that behave as independent clonal lineages (Bayman and Cotty, 1991; Grubisha and Cotty, 2010, 2015; Leslie, 1993). VCGs are determined with a functional assay looking at complementation of auxotrophic mutants (Bayman and Cotty, 1991; Leslie, 1993). Complementation (which indicates membership in the same VCG) occurs when isolates possess identical alleles at each heterokaryon incompatibility (het) locus, which are distributed across multiple chromosomes. Among and, to a lesser extent, within VCGs there exists significant variation in genetic, epidemiological, and physiologic characteristics, including aflatoxin-producing ability (Bayman and Cotty, 1991; Horn and Greene, 1995; Mehl and Cotty, 2010). Members of certain specific VCGs produce large quantities of aflatoxins $(>10,000 \mu \mathrm{g} / \mathrm{kg}$ ), while members of specific different VCGs produce low concentrations of aflatoxins and members of some VCGs produce no aflatoxins at all (Cotty, 1989; Joffe, 1969). VCGs composed entirely of individuals with no aflatoxin-producing ability are known as atoxigenic (Atehnkeng et al., 2016; Grubisha and Cotty, 2015). Inability of members of some VCGs to produce aflatoxins is linked to the presence of several lesions in the genome including deletions and single nucleotide polymorphisms or SNPs (Ehrlich and Cotty, 2004; Adhikari et al., 2016).

To date, the only commercially effective, environmentally friendly technology to reduce aflatoxin accumulation of crops is to use atoxigenic isolates of A. flavus as biocontrol agents to displace aflatoxigenic fungi (Cotty, 2006; Cotty et al., 2008; Dorner, 2004, 2009). This technology was pioneered in the US, where two atoxigenic genotypes (from here on referred as atoxigenic VCGs) are currently registered with the US Environmental Protection Agency (US-EPA) for prevention of aflatoxin contamination. Aspergillus flavus AF36, developed by the Agricultural Research Service of the United States Department of Agriculture (USDA-ARS), was the first biocontrol product registered with the US-EPA for biocontrol of aflatoxin contamination and continues to be used on cottonseed, maize, and pistachio (Cotty, 2006; Cotty et al., 2007; Doster et al., 2014). AF36 is produced and distributed by a farmergoverned and financed organisation, the Arizona Cotton Research and Protection Council (Cotty et al., 2007). The other biocontrol product registered with the US-EPA is Afla-Guard ${ }^{\oplus}$, which is used on maize and groundnut; AflaGuard $^{\circledR}$ is produced and distributed by Syngenta (Dorner, 
2004; Dorner and Lamb, 2006). Use of atoxigenic VCGs to limit aflatoxin contamination throughout the US has allowed maintaining the economic viability of susceptible crops in areas prone to contamination.

Biocontrol applications increase frequencies of atoxigenic VCGs in the treated fields and in so doing less aflatoxins accumulate in treated crops (Cotty, 2006; Cotty et al., 2007; Dorner, 2004; 2009). Atoxigenic VCGs are dispersed with a carrier (i.e. wheat, sorghum or barley grain) that also serves as a nutrient source (Cotty and Mellon, 2006). The biocontrol formulation provides atoxigenic VCGs with both reproductive and dispersal advantages over resident aflatoxin-producers (Cotty et al., 2008). After applications in the field, the atoxigenic VCGs contained in the biocontrol formulation produce conidia on the grain and disperse to other nutrient sources including the target crop. Biocontrol applications are timed before resident Aspergillus populations begin to increase, 2-3 weeks before crop flowering, and this allows for effective displacement of aflatoxin producers. Once established in the treated fields, atoxigenic VCGs create their own founder populations and shift the community composition within the treated area, and to some extent in neighbouring areas, from one dominated by aflatoxin producers to one in which atoxigenic VCGs dominate (Cotty and Mellon, 2006). Neither the overall amount of $A$. flavus in the environment nor the frequency of crop infection increases as a result of applications of atoxigenic VCGs in biocontrol formulations (Atehnkeng et al., 2014; Bock et al., 2004; Cotty, 2006; Cotty et al., 2008; Dorner, 2004, 2009; Doster et al., 2014). Several benefits result after application of atoxigenic VCGs, because these beneficial fungi carry over between crops and provide protection for multiple years and crops. Because fungi can spread, as the safety of fungal communities within treated fields improves, so does the safety of fungal communities in areas neighbouring treated fields. Application of atoxigenic VCGs also provide post-harvest benefits because atoxigenic VCGs move with the treated crop throughout the value chain discouraging contamination during both storage and transport should conditions favouring fungal growth and aflatoxin formation occur (Atehnkeng et al., 2014). Biocontrol is a simple intervention in the field that by itself dramatically reduces aflatoxin contamination in crops from pre-harvest until consumption (Bandyopadhyay and Cotty, 2013).

Use of native atoxigenic VCGs for aflatoxin biocontrol is favoured because of their adaptation to target agroecosystems. Atoxigenic VCGs native to a target area are already adapted to compete for utilisation of local resources in endemic niches and have been selected by the local cropping systems, including local crop rotations and co-cropping (Mehl et al., 2012). In addition, native atoxigenic VCGs are genetic resources of the nations in which they reside and are the property of those nations, allowing national governments to manage the use of such VCGs for maximal benefit of the population (Probst et al., 2011).

\section{Combination of traditional and biocontrol management options}

Aflatoxin biocontrol management has been demonstrated to be effective in consistently reducing aflatoxin contamination in a significant manner (Atehnkeng et al., 2014; Cotty, 2006; Dorner, 2004; Doster et al., 2014; Mehl et al., 2012). Based on this, biocontrol technologies should be considered as the centrepiece of aflatoxin management but supported by adoption of agricultural practices that discourage aflatoxin formation such as rapid drying and good storage along with institutional (e.g. development of aflatoxin conscious markets), policy (e.g. testing facilities), training, and sensitisation actions in order to reduce exposure to aflatoxins throughout sub-Saharan Africa and elsewhere.

\section{Climate change and biocontrol products for aflatoxin mitigation}

Climate change is threatening food and feed security in many regions across the globe, including sub-Saharan Africa (Wheeler and Von Braun, 2013). Frequencies of severe aflatoxin contamination episodes both in regions prone to aflatoxin contamination and regions that as of now are relatively unaffected are expected to increase as a result of hotter, dryer conditions driven by climate change (Battilani et al., 2016; Magan et al., 2011; Paterson and Lima, 2010). Arid and semi-arid zones are increasing across the globe (Reynolds et al., 2007) and this will favour prevalence and dominance of highly toxigenic Aspergillus lineages with S-morphotype (Bock et al., 2004; Cardwell and Cotty, 2002; Cotty, 1997; Cotty and Jaime-Garcia, 2007; JaimeGarcia and Cotty, 2010; Orum et al., 1997; Probst et al., 2014). However, highly toxigenic S-morphotype lineages are successfully managed with biocontrol agents in both arid and semi-arid areas of the US (Cotty, 2006; Cotty et al., 2007; Doster et al., 2014), Nigeria (Atehnkeng et al., 2014), Kenya, and Senegal (unpublished results, see below).

Nations in which the effects of climate change are likely to promote crop aflatoxin contamination should be conducting more research to identify candidate atoxigenic VCGs to be used in biocontrol formulations (Battilani et al., 2016). A recent example for the need of an aflatoxin biocontrol management tool in an area relatively unaffected by aflatoxin outbreaks occurred in Mexico. Aflatoxin contamination events were anticipated to occur in maize planted over hundreds of thousands of hectares as a result of an extended cropping season that resulted in maize exposure to hot, dry temperatures; however, biocontrol technologies were not available to farmers and this resulted in high aflatoxin concentrations with some maize lots contaminated with 
up to $500 \mu \mathrm{g} / \mathrm{kg}$ aflatoxin $\mathrm{B}_{1}$ (Ortega-Beltran et al., 2016). Other nations should learn from this and other aflatoxin contamination episodes (e.g. in Italy and Serbia; Kos et al., 2013; Camardo-Leggieri et al., 2015) and be prepared with aflatoxin biocontrol management technologies for the climatic challenges that will be faced in the near future.

For those areas in which biocontrol technologies are currently used, biocontrol formulations could be further improved by incorporating seed technologies that would allow for better sporulation rates of the atoxigenic VCGs under hot, dry conditions driven by climate change. A variety of seed treatments allow improving both plant growth and productivity (Conrath et al., 2006; Jisha et al., 2013; Taylor and Harman, 1990). One of those technologies, hydropriming, is used to increase seed germination rates under low moisture conditions (Ghassemi-Golezani et al., 2010; Kaur et al., 2002). Hydropriming biocontrol formulations based on grains (e.g. sorghum) could allow rapid germination and sporulation of the biocontrol isolates. Biocontrol formulations could also contain a super adsorbing polymer that would allow grains to capture moisture from the environment (e.g. soil or air) (Wang et al., 2003; Yang et al., 2014) in order to enhance faster, uniform sporulation rates by the atoxigenic VCGs. Increasing the repertoire of technologies in a biocontrol formulation would provide additional confidence of its effectiveness in any given environment.

Continuous monitoring of weather parameters, types of aflatoxin-producing fungi, and crop aflatoxin accumulation across countries will contribute to a better understanding of the influences of climate change on the aflatoxin contamination process on a large scale. Such understanding will allow implementing aflatoxin management strategies based on weather events that may include selection of atoxigenic VCGs adapted to both hotter-dryer climates and changes in cropping cycles (Cotty and Jaime-Garcia, 2007).

\section{Biocontrol agents in Africa, the trade name Aflasafe}

The success of biocontrol products as biopesticides in the US encouraged researchers of the International Institute of Tropical Agriculture (IITA) and the USDA-ARS to develop, adapt, and improve the biocontrol approach for African agroecosystems. Collaboration among IITA, USDA-ARS, and several partners has resulted in both successful adaptation of the biocontrol technology for use on maize and groundnuts in various African nations and development of several biocontrol products under the trade name Aflasafe (Atehnkeng et al., 2014; Bandyopadhyay and Cotty, 2013). In the US, biocontrol products contain a single atoxigenic VCG as the active ingredient. Aflasafe products belong to the second generation of biocontrol products constituted with four unique atoxigenic VCGs.
The multi-VCG strategy may provide stable, long-term and additive beneficial effects in diverse environments (Mehl et al., 2012; Probst et al., 2011). Certain Aflasafe products consist of atoxigenic VCGs native to a particular nation while others have been developed with atoxigenic VCGs native to more than one nation. As a matter of principle, non-native VCGs (exotics) are not used in Aflasafe products to avoid risks to ecosystems posed by the introduction of exotic microorganisms (Probst et al., 2011; Simberloff and Stiling, 1996). Also, regulatory agencies are more likely to accept the use of native atoxigenic VCGs in comparison with exotic VCGs.

Atoxigenic VCGs composing the different Aflasafe products are selected by examining several thousand isolates of Aspergillus obtained from several hundred crop samples across a target country/region. A comprehensive analysis of the Aspergillus population across target areas allows an understanding of the natural diversity of populations of aflatoxin-producing fungi. Selection of atoxigenic VCGs is designed based on community compositions of the Aspergillus population in a target area. An array of intensive microbiological, DNA, chemical and field tests allows identifying widely adapted atoxigenic VCGs with superior abilities in reducing aflatoxin accumulation.

Atoxigenic VCGs composing any Aflasafe product comply with the following characteristics: (1) belong to the L-morphotype of A. flavus; (2) are atoxigenic as a result of SNPs, deletions, and/or insertions in genes of the aflatoxin biosynthetic pathway; (3) produce no or, in exceptional cases, low amount of cyclopiazonic acid; (4) their members solely consist of atoxigenic isolates; (5) reduce aflatoxin accumulation by more than $90 \%$ when co-inoculated with highly toxigenic fungi on both maize and groundnut; (6) are dominant in both the target agroecosystem and target crop; and (7) have superior capacity to reduce aflatoxin when applied in the field.

To date, Aflasafe products have been registered for use in Nigeria as Aflasafe in 2014 (Figure 1A), in Kenya as Aflasafe KE01 in 2015, and Senegal/The Gambia as Aflasafe SN01 in 2016 (Figure 1B). Research is currently underway to secure registration of tailor-made Aflasafe products in Burkina Faso, Burundi, Ghana, Malawi, Mozambique, Rwanda, Tanzania, Uganda, and Zambia. The current IITA strategy is to develop regional Aflasafe products constituted with atoxigenic VCGs already co-occurring in several target nations. This approach serves the dual needs of native nature of the constituent active ingredients in the Aflasafe products as well as expanding the potential market reach of the products to several nations in a region. For example, Aflasafe SN01, a product initially developed for Senegal, is used in The Gambia because the atoxigenic VCGs constituting Aflasafe SN01 are also native to The Gambia. Similarly, regional products are currently under 

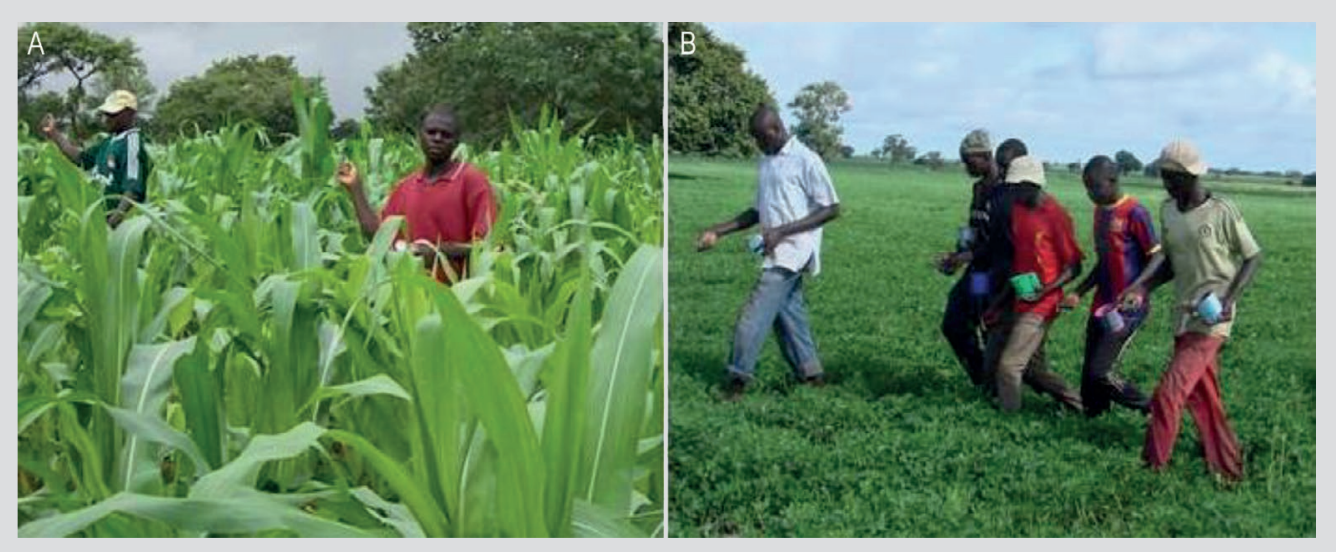

Figure 1. Farmers applying Aflasafe in maize in Nigeria (A) and Aflasafe SN01 in groundnut in Senegal (B).

testing in Ghana, Malawi, Mozambique, and Tanzania. New Aflasafe product development for other nations in Africa would be regional ones when appropriate.

\section{The first Aflasafe biopesticide}

With funding from the German Government, more than 4,200 Aspergillus isolates collected from maize and soil samples in Nigeria in 2003 were subjected to diverse studies that helped to identify 20 atoxigenic VCGs native to the major maize-producing regions of Nigeria (Donner et al., 2010). Representative isolates of the 20 atoxigenic VCGs were evaluated in laboratory experiments for growth rate, reproduction (sporulation), and ability to reduce aflatoxins when challenged with highly toxigenic isolates (Atehnkeng et al., 2008). Each of the four atoxigenic VCGs that performed superiorly in laboratory conditions was integrated into an experimental biocontrol formulation for field evaluation on maize grown in four agroecological zones in Nigeria during 2007 and 2008 (Atehnkeng et al., $2014,2016)$. Use of the experimental formulation resulted in 67 to $95 \%$ less aflatoxins in treated fields in comparison to untreated control fields. The aflatoxin reductions were associated with over $75 \%$ combined incidence of the four atoxigenic VCGs on treated maize. Among the four atoxigenic VCGs used in the experimental product, one was not frequently isolated from treated fields suggesting its unsatisfactory adaptation (Atehnkeng et al., 2016) and was replaced with a more efficient VCG in the final product trademarked as Aflasafe. After subsequent improvements in the formulation, Nigeria's National Food and Drug Administration and Control (NAFDAC) approved in 2014 the full registration of Aflasafe for use in both maize and groundnut. The obtained results demonstrated that the evaluated multi-VCG product had the potential to reduce aflatoxin accumulation in Nigeria and this sparked interest to develop biocontrol products using mixtures of atoxigenic VCGs for other African nations.

\section{Construction of an Aflasafe manufacturing plant in Nigeria}

During the initial phase of Aflasafe product efficacy testing, both Aflasafe product and maize produced from Aflasafetreated fields by farmers were in high demand in niche markets. The end-user sectors with the most demand were the poultry industry and quality-conscious food industries, which had the most awareness about aflatoxins. This demand was created using an 'innovation system' through which poultry producers learned that incorporation of maize from Aflasafe-treated fields in poultry feeds reduced bird mortality by $70 \%$, which in turn increased profits by US\$ 320 for every 1000 birds over a two month period (unpublished results).

During the testing phase, the experimental product was manufactured using a slow and labour-demanding laboratory-scale process (Atehnkeng et al., 2014) which allowed production of only a few metric tons of the product per month. In order to increase Aflasafe availability to satisfy its demand, a manufacturing plant was constructed with funds provided by the Bill and Melinda Gates Foundation (BMGF) through the Partnership for Aflatoxin Control in Africa (PACA). When operating at full capacity, the plant is capable of producing 5 tons of Aflasafe per hour. To date, the plant has produced well over 700 tons of Aflasafe products for use in Nigeria, Kenya, Senegal, Ghana, Mozambique, Zambia, Tanzania, The Gambia, and Burkina Faso.

The purpose of constructing the Aflasafe demonstrationscale manufacturing plant was to demonstrate that a biocontrol manufacturing plant can be constructed at a relatively low cost with material and equipment that is available throughout Africa: an industrial seed roaster, a cooler, a seed treater, and packaging equipment (Figure 2). This equipment is commonly used by seed companies and feed manufacturers that operate in Africa and elsewhere. Another objective of constructing the manufacturing plant 

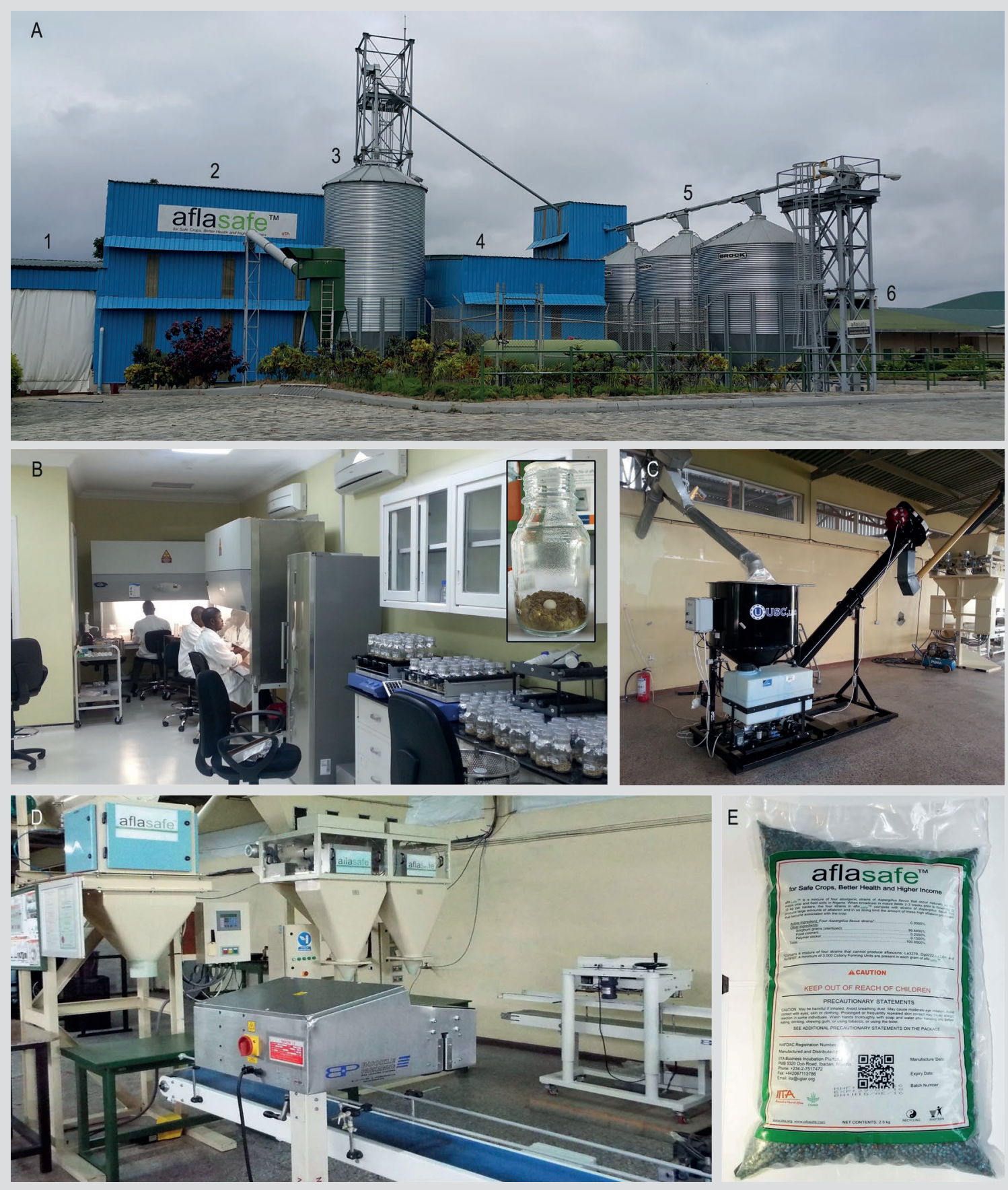

Figure 2. (A) External view of the Aflasafe demonstration-scale manufacturing plant at the IITA campus in Ibadan, Nigeria. The plant consists of: (1) grain intake pit; (2) sorghum debearder and a 3-stage grain cleaner; (3) a grain silo of 100 ton capacity to store clean grains; (4) roaster to sterilise grains and cooler to cool the hot roasted grains; (5) three grain silos of 50 ton capacity each to store sterilised grains; and (6) inoculum production and quality control laboratories. (B) Laboratory where inoculum is produced en masse. Inset: bottle containing sorghum colonised by an atoxigenic isolate; spores are harvested to prepare a spore suspension for biocontrol formulation. (C) Commercial seed treater to coat sterile sorghum grains with a spore suspension containing one isolate each of four atoxigenic VCGs. (D) Weighing and packaging lines of coated products. (E) A finished package of Aflasafe product.

was to eventually seek expressions of interest by private and/ or public sector organisations to take over manufacturing. Several companies have expressed interest to manufacture and distribute Aflasafe products in Nigeria, Kenya, Senegal, Malawi, and Zambia. 


\section{Cost of Aflasafe products}

The estimated cost to produce Aflasafe product to treat one hectare, $10 \mathrm{~kg}$, ranges from US\$ 7 to US\$ 12 depending on the currency exchange rate and price of the constituents: sorghum grain as carrier, polymer for spores to stick to sorghum, a blue dye to differentiate the product from regular sorghum, and laboratory material and reagents used for inoculum preparation and quality control tests. It is estimated that distributors will make a meaningful profit by charging around US\$ 12 to US\$ 18.75 to end users, enabling the companies to cover distribution and extension costs. To recover investment on the product, farmers need to receive a roughly 1 to $4 \%$ premium on their grain depending on maize/groundnut yield and market prices and assuming they hold back 1 ton of maize or 0.3 tons of groundnut for family consumption.

\section{Registration}

Prior to large-scale use in a target nation, biocontrol products must be registered as biopesticides with the respective national biopesticide regulatory agencies. Registration is granted when enough evidence on efficacy, safety, quality, and social/economic value of a product is provided. Several efficacy, toxicology, and eco-toxicology parameters must be satisfied prior to registration and gathering such data is expensive. However, except in a few African nations, the biopesticide registration procedure is not well developed. Efforts are underway to develop regional guidelines for biopesticide registration to enable the use of biopesticides in all nations in the region when approved by the regional regulatory agency. For biopesticide registration in some nations, a fast-track system is in place that allows requests for science-based waivers for some registration data requirements but negotiations for such waivers for registration are a significant challenge. To overcome this problem, regulatory agencies and key senior policymakers are consulted and sensitised before biocontrol product development begins in each nation. These agencies are considered partners in the development process and their advice is incorporated into research. For example, Nigeria's NAFDAC required a poultry-feeding study with Aflasafe to determine the safety of the product and waived other toxicity data requirements when the product was found safe in the study. During registration of Aflasafe KE01 in Kenya, the Pest Control Products Board (PCPB) demanded certain toxicological and eco-toxicological studies to be conducted but waived others based on the evidence that atoxigenic biocontrol products used in the US are environmentally safe (US-EPA, 2003, 2004).

\section{Scaling-up Aflasafe in Nigeria}

AgResults (www.agresults.org) is a collaborative initiative between the BMGF, the governments of Australia, Canada, the United Kingdom, and the US that incentivises and rewards high-impact agricultural innovations that promote food security, health, and nutrition. The initiative does this through the design and implementation of pull mechanisms, an innovative finance mechanism that provides economic incentives to the private sector in order to enter into markets that serve those living in extreme poverty.

AgResults hosts six projects that implement pull mechanisms across the world including the Nigeria Aflasafe Pilot. The Nigeria Pilot incentivises the adoption of Aflasafe among Nigeria's maize farmers. The pilot expects the production of at least 260,000 tons of maize ( $3 \%$ of Nigeria's maize production) containing low aflatoxin concentrations by 2018. It is expected that farmers will keep 60,000 tons of maize for their consumption and 200,000 tons will enter both formal and informal markets in Nigeria. The project has created aflatoxin awareness among farm families, food/feed processors, and consumers to support the adoption process.

The Nigeria Pilot relies on private and public sector enterprises (known as implementers) to aggregate maize produced by smallholder farmers. Implementers receive training on technologies to produce maize with low aflatoxin concentrations, with the use of Aflasafe as a centrepiece, and information on maize buyers seeking aflatoxin-safe maize. Implementers pass the acquired knowledge to their farmers and provide inputs and farm services such as highyielding seeds and fertilizers, Aflasafe, amongst others. Most of the maize produced by participating smallholder farmers is purchased and aggregated by corresponding implementers who in turn sell the treated maize in markets seeking aflatoxin-safe maize. During the 2012/2013 season, quality conscious buyers paid up to a $13.5 \%$ premium over the market price for maize aggregated from Aflasafe-treated farms. The return on investment was up to $510 \%$ for treating fields with $10 \mathrm{~kg}$ Aflasafe per hectare purchased at a cost of US\$ 1.875 per $\mathrm{kg}$. It is worth noting that the participating farmers retain a significant portion of the maize for their own home consumption and this results in health benefits for their families, including women and children (Grace et al., 2015; Wu and Khlangwiset, 2010).

Aggregation of maize avoids force-selling and allows taking advantage of high off-season prices. Aflatoxins are quantified in the aggregated maize to determine if the treated crop meets quality standards of high-end food and feed processors (e.g. the poultry industry and premium food sectors). In addition, the aggregated maize is examined for the presence of Aflasafe atoxigenic VCGs. This allows determining if farmers applied Aflasafe in their fields. The 
Nigeria Pilot incentivizes implementers with US\$ 18.75 for every ton of aggregated maize containing a high frequency of Aflasafe VCGs. In 2012/2013, nearly 99\% maize grain lots from implementers' fields contained less than $20 \mu \mathrm{g} / \mathrm{kg}$ total aflatoxins (www.agresults.org/en/283/), an aflatoxin level considered safe to eat as per the US Food and Drug Administration standard. High frequency of Aflasafe VCGs and low aflatoxin concentrations benefit both implementers and farmers who receive a premium from the market and incentives from the Nigeria Pilot. In fact, the implementers realised that more profits are obtained from the market premium than the incentives received from AgResults. Implementation of the AgResults initiative in Nigeria demonstrates that it is possible to profitably scale up adoption of Aflasafe by smallholder farmers through a mix of technical (Aflasafe and other management practices), institutional (farmer groups and premium markets), and policy (incentivisation) innovations (Grace et al., 2015).

\section{Scaling-out in other nations}

\section{Kenya}

Aflasafe KE01, a product developed for use in maize in Kenya, was registered by the $\mathrm{PCPB}$, the Kenyan biopesticide regulator, in 2015. There is high aflatoxin awareness in Kenya because dozens of people have died of aflatoxin poisoning after eating contaminated maize; the nation, unfortunately, features some of the world's most aflatoxin-prone areas (Probst et al., 2007, 2012). In 2014, the Kenyan Government disposed of 13,950 tons of maize containing dangerous aflatoxin concentrations which were worth US\$ 5 million. Because of the maize needs of Kenya, the Government has invested in highly mechanised irrigation schemes in large areas in the Hola and Bura districts in order to increase maize production. These areas are promoted as food security zones by the Government of Kenya. However, large portions of these districts are hotspots for aflatoxin contamination and if successful pre-and post-harvest interventions are not implemented the original food security objective of the Government will not be achieved. In 2015, the Kenyan Government procured 270 tons of Aflasafe KE01 to treat these areas, including 8 tons that were air-lifted to treat on an emergency basis. Aflasafe KE01 was produced in IITA's Aflasafe manufacturing plant for distribution by the Ministry of Agriculture in the aflatoxin-prone areas of 11 counties in order to improve food safety as a public good initiative. Use of Aflasafe KE01 successfully reduced aflatoxin in all treated fields by allowing accumulation of less than $4 \mathrm{ng} / \mathrm{g}$ total aflatoxins in $99 \%$ of the fields (unpublished results). The Kenyan Government aims to treat more than 537,000 ha of maize in the next few years in a trial phase. Producing that quantity of Aflasafe KE01 in Nigeria and transporting it to Kenya is not economically feasible. In order to satisfy Aflasafe KE01 demand in Kenya,
IITA, USDA-ARS and Kenya Agricultural and Livestock Research Organization (KALRO) are building a modular manufacturing plant in Machakos. The modular plant will be handed over to the KALRO after commissioning. This plant will supply Aflasafe KE01 to the Kenyan Ministry of Agriculture for area-wide treatment as well as to farmers. The Government of Kenya - at the Federal, State, and County levels - has indicated its interest in paying for the manufacturing and distribution of Aflasafe KE01 as a public good to areas that are repeatedly affected by both aflatoxin contamination events and aflatoxicosis outbreaks. This public sector model will create demand for the product initially for public good. It is envisaged that the production and marketing of Aflasafe KE01 will be handled by private sector actors in Kenya in due course.

\section{Senegal and The Gambia}

Aflasafe SN01, a product initially developed for use in both maize and groundnut in Senegal was registered by Le Comité Sahélien des Pesticides (CSP) of Comité InterEtate pour la Lutte contre la Sécheresse au Sahel (CILSS) in 2016 for potential use in 12 CILSS nations. The Direction de la Protection des Végétaux (DPV) of the Government of Senegal has led the large-scale field testing of Aflasafe SN01 over a six year period (2010-2015). More than 1000 farmers participated in field efficacy trials. Use of Aflasafe SN01 resulted in aflatoxin reductions by 75 to $93 \%$ at harvest and by 86 to $95 \%$ after three months of storage in comparison to crops harvested from control fields (unpublished results). SODEFITEX (www.sodefitex.sn), a private company based in Senegal, has expressed interest in manufacturing and distributing Aflasafe SN01. SODEFITEX is a large commercial vertically-integrated farmer cooperative with over 70,000 smallholder groundnut and maize farmers who receive input and output marketing support from the company. Their interest in Aflasafe SN01 is partly to help their farmers produce groundnuts of sufficient quality to export to Europe. SODEFITEX also plans to sell Aflasafe SN01 to other groundnut exporters in Senegal who would similarly use it to secure supply chains free of aflatoxin. Furthermore, because the atoxigenic VCGs of Aflasafe SN01 are also native to The Gambia, Aflasafe SN01 has been tested in groundnut fields of that nation and similar efficacy results as those obtained in Senegal have been achieved. The National Food Security Processing and Marketing Corporation of The Gambia has begun to implement a similar scale-up model as in Senegal but will import Aflasafe SN01 from the manufacturing plant in Senegal.

\section{Other nations}

Aflasafe products are under different development stages in nine other nations (Figure 3). A dossier for registration of Aflasafe BF01, developed for Burkina Faso, is under preparation for submission to the CSP of CILSS by the 


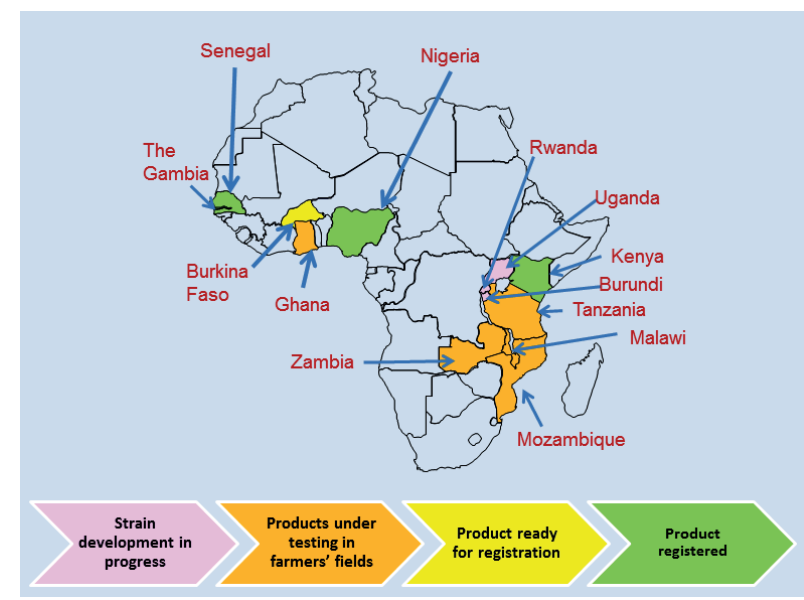

Figure 3. Status of the stages of Aflasafe product development in various African nations as of August 2016.

end of 2016. For Zambia and Ghana, sufficient efficacy data would be available to begin the product registration process in 2016 and 2017, respectively. Work on VCG selection/testing of Aflasafe products continues in Burundi, Malawi, Mozambique, Rwanda, Tanzania, and Uganda. Authorities in Mali and Democratic Republic of Congo have also expressed interest in developing Aflasafe products for their nations.

The previous efforts to scaling-up use of Aflasafe products throughout Africa were primarily supported by the US and Austrian Governments and the BMGF. A proposal to scale-up the use of Aflasafe products through technology transfer and commercialisation was approved by the BMGF and the United States Agency for International Development (USAID) in 2015. This initiative will allow smallholder farmers in 11 nations to have access to Aflasafe products for treating at least 500,000 ha of maize and groundnut fields over a five-year period. Use of Aflasafe products will result in the production of well over 1 million tons of aflatoxin-safe maize and groundnut valued at approximately US\$ 325 million. The project will leave behind public, private, and public-private sector led systems for sustained use of Aflasafe products for several years after the project ends. Aflasafe adoption throughout the 11 target nations will be achieved by the following drivers: (1) development of premium markets for aflatoxin-safe grain such as exports, animal feed producers, and high-quality domestic consumers; (2) promotion of public sector driven health campaigns; (3) creation of dedicated manufacturing and distribution channels; and (4) identification of how businesses react to increased regulatory enforcement and consumer demand. The project will focus on a mix of the first two drivers which, between them, exist to varying degrees in the 11 nations today. The third will emerge gradually and unevenly across the nations as more clean grain allows for greater regulation and enforcement.

\section{Challenges to scale-up adoption of Aflasafe products}

Technical, institutional, and market challenges for technology transfer and scaling-up Aflasafe as an agricultural input will be faced in each target nation. National regulatory authorities must approve the use of Aflasafe products, legal agreements must be developed for transfer of technologies, manufacturing plants must be designed as per needs, and value propositions for the use of an Aflasafe product in maize and groundnut value chains by public and private sectors must be well-articulated. The Aflasafe team, along with collaborators, is addressing those challenges by allocating the required resources for developing and executing strategies for identifying investors for manufacturing and distribution, transfer of Aflasafe technologies to these entities, and technically backstopping these partners during the start-up and initial stages of scale-up execution. In addition, substantial efforts will be made in order to complete registration, liaising with governments, developing national strategies, negotiating technology transfer agreements, and testing for quality and efficacy of Aflasafe products.

Registration of Aflasafe products has been a major challenge. There are very few registered biopesticides in Africa and only a few African nations have a dedicated biopesticide registration process separate from the chemical pesticides one. Biocontrol of aflatoxins through competitive displacement is also a novel concept for regulators, some of whom need a good understanding of the technology, its perceived environmental risks, and the biopesticides' registration process. With support from USAID/USDAForeign Agricultural Service, several national and regional biopesticide registration training workshops have been conducted since 2009 in East, West, and Southern Africa in partnership with the Regional Economic Commissions in Africa. Most of the relevant regulators have attended these workshops and trainings, and have become familiar with efficacy and risk assessment procedures followed for registration of aflatoxin biocontrol products and also gained an understanding of the technology. Regulatory agencies and key senior policy-makers were consulted and sensitised before initiation of biocontrol research in each country and in all cases they agreed that aflatoxin biocontrol is in the national interest of public health. These agencies were considered as partners in research and development (R\&D) of Aflasafe products. They were kept informed of key $R \& D$ steps and their advice was incorporated into the research process. These steps enabled building trust and understanding about the technology. With Aflasafe products fully registered in Nigeria, Kenya, and CILSS countries (e.g. Senegal and The Gambia), it is projected that obtaining registration in other nations will be less demanding and time-consuming. 
Another challenge is that private sector actors of certain nations may not ultimately show interest in manufacturing or distributing Aflasafe products. With price controls likely to be agreed on, Aflasafe will be, by design, not an enormously profitable product in order to allow a significant return on investment for smallholder farmers. Still, use of Aflasafe products has the ability to unlock formal markets which the interested productive sectors, such as groundnut export markets and feeds for the poultry industry, might be trying to access. Furthermore, given the high profile of aflatoxin challenges, the use of Aflasafe as an important advance for health and trade issues has generated deep interest among reputable partners in Nigeria, Kenya, and Senegal, where the work is furthest along.

An additional challenge is the lack of adequate understanding among the manufacturers and distributors about the biological nature of Aflasafe and its associated implications on purity, quality, and performance of the product. Not addressing this risk may lead to deterioration of quality, performance, and reputation of the product. To mitigate this risk, a backstopping team of IITA, with engineering, microbiology, pathology, and business development expertise, will guide and mentor the manufacturing/distribution partners on the engineering aspects of manufacturing, microbiological aspects of product manufacturing and quality control, field aspects of product performance, and business aspects of output marketing during the start-up phase.

Consumer willingness to pay, which to some extent is linked to lack of adequate awareness of the negative health impact of aflatoxins, is another challenge to scale-up the use of Aflasafe products. However, the AgResults Aflasafe Nigeria Pilot has demonstrated that it is possible to generate market linkages and that there are attractive monetary incentives and health/family welfare reasons for adoption of Aflasafe products by smallholder farmers. On the other hand, it is unclear how many smallholders these systems cover and whether smallholders will actually be willing to pay for the product themselves with cash upfront in a widespread way. Limited consumer testing to date by IITA has shown promise, but only an attempt to sell at scale will actually test the demand case. There will be the need to develop innovative branding mechanisms, coupled with awareness campaigns, to create premium products with low-aflatoxin concentrations. It is also expected that the manufacturing/distribution partner would advertise and conduct marketing campaigns to increase sale and adoption of Aflasafe products.

\section{Concerns posed by the use of Aflasafe products}

Benefits of aflatoxin management strategies based on atoxigenic biocontrol products are recognised and appreciated by several sectors (e.g. public health, agricultural, trade, development investment, among others) in nations where such strategies are employed. However, new innovative technologies frequently receive scepticism from academic, industrial, and governmental institutions. Planned use of Aflasafe products throughout sub-Saharan Africa has raised questions whether their use pose unnecessary risks to human and/or agroecosystems even though an evidence based case for effective and safe use in the public interest is made prior to product registration by regulatory authorities. Atoxigenic biopesticides are used on over 1 million acres of maize (grain and silage), cotton, groundnuts, and pistachios each year in the US, in areas conducive for aflatoxin-producing fungal infection and subsequent aflatoxin formation, which account for approximately 10 million acres; relatively few biopesticides are used in more than $10 \%$ of any given area (Chandler et al., 2011). In some US regions, either endusers require treatment or farmers would not take the risk of contamination costs as the result of not treating. In the US, farmers and other industry components frequently understand how the technology is meant to work and are aware of both long-term and area-wide benefits. Although in some regions atoxigenic VCG use is considered a normal cost of producing a crop (Smith, 2011a; b), atoxigenic biopesticides in the US were not well accepted during initial development (Kilman, 1993) but agricultural industries and farmers supported and helped implement the technology (Cotty et al., 2007).

The Aflasafe team, composed of IITA, USDA-ARS, and several national partners, has invested substantial efforts in identifying, selecting, and testing atoxigenic VCGs in different African nations to generate the necessary information required to register Aflasafe products with regulatory authorities. The overarching focus continues to be making the Aflasafe technology reach as many farmers as possible in the shortest possible time for improving health, trade, and income in sub-Saharan Africa. This has required devoting resources primarily to submissions of voluminous documentation to, and extensive interactions with regulators for registering products resulting in delayed journal publication. Placing emphasis on implementation, and not capturing credit is contrary to the culture of many institutions in regions where the technology is not routinely practiced by industry with routine assessments of fungal populations, has resulted in ambiguous opinions about biocontrol efficacy.

\section{Use of sorghum as the carrier and nutritive source}

Sorghum is a key staple grain in many sub-Saharan regions (Dicko et al., 2006). Therefore, there is the notion that using sorghum as both the carrier and nutritive source of Aflasafe products contribute to an increase in food insecurity. However, $10 \mathrm{~kg} / \mathrm{ha}$ of Aflasafe allows production of either maize or groundnut with little to no aflatoxins. Much of 
these crops contribute marginally to food security because, in the absence of Aflasafe treatment, their presence in the markets would result in consumption of unsafe aflatoxin concentrations. Thus, a very small quantity of sorghum allows a 100 to 300 -fold increase in safe food based on a 1 to 3 ton crop yield. Moreover, sub-Saharan African nations produce large sorghum quantities with Nigeria producing 6,741,100 metric tons in 2014 (FAO, 2016). Manufacture of sufficient Aflasafe to treat 1 million hectares will subtract less than $0.15 \%$ of the total sorghum production of Nigeria. Nevertheless, investigations have begun to evaluate other substrates, such as cassava peel to replace sorghum as the carrier in order to reduce the price of the formulated product (Okike et al., 2015). The search for improved formulations seeks improved cost effectiveness.

\section{Distribution of Aflasafe products to distant locations}

It has been pointed out that the cost of Aflasafe products will increase when distribution costs are added to the final price of the product. Currently, there is only one Aflasafe manufacturing plant in Africa located in Nigeria. Price of Aflasafe in Nigeria includes 3 to 5 cents $/ \mathrm{kg}$ cost of transportation. But, shipping outside of Nigeria is expensive. Plans to facilitate local manufacturing and distribution of Aflasafe across sub-Saharan Africa are in place. Indeed, an Aflasafe modular manufacturing plant is under construction in Kenya and another is under design in Senegal. As incountry manufacturing comes on line, product costs will decrease. In Nigeria, the AgResults Aflasafe Pilot distributed Aflasafe across the country at one fixed price not influenced by transportation cost. Business models must incorporate the costs of production and distribution within final product cost.

\section{Aflatoxin conscious markets drive adoption}

Lack of aflatoxin awareness, poorly enforced regulations (wherever these exist and/or are applied), and lack of discrimination in markets for low aflatoxin crops are major obstacles to adoption of aflatoxin prevention technologies. However, quality conscious markets have consistently demanded aflatoxin-safe commodities in Africa. These include food processors, poultry industries, groundnut exporters, and anchor buyers who are willing to pay premiums for quality. For example, total projected maize requirement for the Nigerian feed industry was 1.8 million tons in 2013/2014 (Heise et al., 2015) providing demand for low-aflatoxin maize for the aflatoxin sensitive poultry industry. In addition, markets will be expanded by health ministries in partnership with nutrition-sensitive development programs promoting benefits of Aflasafe products as public goods.

Admittedly, promoting commercialisation and adoption of Aflasafe technologies with linked development of quality- conscious markets are not easy tasks in any target nation. Commercialisation of Aflasafe products is underway through market approaches. In Nigeria, the AgResults Aflasafe Pilot project brings together the poultry industry (predominantly from the south) with the maize producers (predominantly from the north) in annual meetings in order to drive markets for aflatoxin-safe maize. Similar approaches tailored to specific industries will be pursued across subSaharan Africa in order to further develop aflatoxinconscious markets. It is expected that commercialisation of Aflasafe products will continue to scale-up for half a decade, a period over which perseverance will be important.

\section{Efficacy of Aflasafe during drought}

Concern has been expressed that atoxigenic VCGs will not sporulate on carrier grain under low humidity during severe drought conditions. Aflasafe applications are timed to coincide with frequent rainfall and high soil moisture. When drought conditions prevail after application, the active ingredient fungi remain alive on the carrier grains and will sporulate when the conditions are conducive. Sporulation has also been observed under drought conditions with low soil moisture on carrier grains that are lodged under the plant canopy with the canopy both protecting the carrier and providing humidity for night sporulation.

Use of the atoxigenic biopesticide Aspergillus flavus AF36 throughout the desert valleys of Arizona and drought-prone maize production in Texas and pistachio production in California allows production of crops with low aflatoxin concentrations regardless of aflatoxinconducive environmental conditions (Cotty, 2006; Cotty et al., 2007; Doster et al., 2014). The active ingredient of AF36 is native and adapted to hot, dry conditions and therefore use of AF36 is effective under those conditions. The two atoxigenic biopesticides in the US, Afla-Guard ${ }^{\oplus}$ and AF36, are used annually on over a million acres of maize, pistachio, groundnut, and cottonseed. AF36 has been applied to commercial fields for over two decades and industry continues to see economic justification for its use. In Africa, more insights on the efficacy of an Aflasafe product tested over diverse agroecosystems have been gained in Senegal's groundnut basin, where more than 100 efficacy trials using Aflasafe SN01 have been conducted in each of the last six years (2010-2015) in three agroecological zones. One of these agroecological zones, around Diourbel, is more drought-prone than the others. Nevertheless, aflatoxin reductions (over 80\%) were obtained both at harvest and after storage in all three agroecological zones (unpublished results). The active ingredients of Aflasafe SN01 have widespread distribution in Senegal, including the drought-prone areas. Therefore, it was expected that the biopesticide would be effective throughout the area. For all Aflasafe products, only atoxigenic VCGs most successful in the target agroecological zones are selected as active 
ingredients to ensure selected VCGs are adapted to perform well in the target environments.

\section{Post-harvest benefits provided by Aflasafe products}

The idea that use of Aflasafe products does not provide post-harvest benefits is incorrect and should be discarded. Aflatoxin-producing fungi become associated with and infect crops in the field. Although contamination frequently occurs prior to harvest, aflatoxin-producing VCGs remain with crops during harvest, transport, and storage, until consumption. If the environment where crops are stored and/or transported is humid and warm, crop infection and the contamination process may continue. Biocontrol with atoxigenic VCGs disrupts this by allowing fewer aflatoxinproducers to move into storage thus providing extended protection should conditions for fungal proliferation occur (Cotty, 2006). Use of Aflasafe in Nigeria resulted in lower aflatoxin contamination both at harvest and after poor storage (Atehnkeng et al., 2014). Extended protection of both maize and groundnut from aflatoxin contamination during poor storage conditions has been detected when using Aflasafe products in Senegal, Ghana, and other African nations (unpublished results). Therefore, use of Aflasafe products reduces the source of aflatoxins in the environment, during both crop development and postharvest storage, during transport, and throughout the value chain until commodities are consumed.

\section{The risk of allergies and/or aspergillosis}

Prior to registration of the biocontrol products in the US and Africa, the US-EPA, NAFDAC, and PCPB were concerned about potential harmful effects of using atoxigenic VCGs as biocontrol agents because of human allergies and infections caused by Aspergillus fumigatus (Latgé, 1999). Risk assessment studies on allergies (e.g. skin, eye, and inhalation) following standard protocols to determine Globally Harmonised System of Classification and Labelling of Chemicals proved that Aflasafe KE01 in Kenya and AF36 in the US deemed biocontrol products as non-toxic. Studies to support AF36 registration indicate applications may be made without increasing densities of A. flavus on the crop and in the air (Bock et al., 2004). Increases in overall densities of Aspergillus species have not been detected when applying AF36 on several crops in the US (Bock et al., 2004; Cotty et al., 2007; Doster et al., 2014). Similar results occurred with Aflasafe products in Nigeria (Atehnkeng et al., 2014) and Kenya, Ghana, Senegal, Burkina Faso, Zambia, Mozambique, Tanzania, and The Gambia (unpublished results). Thus, applications to developing crops with atoxigenic VCGs do not increase the amount of Aspergillus that will exist on the mature crop. Biocontrol products are applied when Aspergillus populations begin to increase. These applications trigger beneficial founder effects by dispersing the biocontrol VCGs prior to aflatoxin-producers. However, the ultimate quantity of Aspergillus on the crop is independent of the applications and driven by the environment and available resources for fungus reproduction.

Personnel working in Aflasafe manufacturing plants have minimal exposure to the active ingredient fungi during manufacture. Manipulations associated with spore production occur under aseptic conditions in Type 2 biosafety cabinets. Fungus growth and spore production are in sealed jars. Conidia are harvested and mixed with a sticker and colourant also in a Type 2 biosafety cabinet. The polymer sticker, commonly used in the seed industry, makes the spores adhere to the carrier surface after coating in an automated seed treater similar to those used to coat seed with highly toxic insecticides and fungicides. The end-use product is sealed in a package for shipment to distributors and farmers.

The spores that distribute throughout treated fields and to the developing crops are formed by the Aflasafe active ingredients several days after application. Applicators in the field are not exposed to these spores. Applicators of Aflasafe products and farm workers are advised to avoid conducting field activities in treated fields during 10 days following application in order to avoid burying the product grains. Application does not increase the quantity of $A$. flavus in the fields but reduces incidence of aflatoxin-producers and human exposure to the aflatoxin-containing spores of aflatoxin-producers (Bock et al., 2004; Mehl and Cotty, 2010). Exposure to Aspergillus remains the same in treated and untreated fields.

\section{Influence of Aflasafe products on the accumulation of other mycotoxins}

Aflasafe products seek to decrease aflatoxins concentrations in both treated and subsequent crops. Critics of the technology indicate that use of Aflasafe products does not reduce concentrations of mycotoxins produced by other species. However, Aflasafe products are not designed and cannot be expected to reduce all mycotoxins forming in maize and/or groundnut. Fumonisin was quantified in maize grains sampled from 136 paired farmers' fields -68 Aflasafe-treated fields and one untreated field adjoining each treated field - during 2009 to 2012 in two states in Nigeria. There was no significant difference in fumonisin concentration in treated and control grains in any of the three years. Mean fumonisin concentration in grains from Aflasafe-treated fields were $0.49 \mu \mathrm{g} / \mathrm{g}$ compared to 0.44 $\mu \mathrm{g} / \mathrm{g}$ in control fields ( $P=0.77$ in Student's paired $t$-test). The above results are contrary to the unsubstantiated speculation of Alberts et al. (in press) that biocontrol 
technologies will increase fumonisin concentrations in treated maize fields.

\section{Influence of Aflasafe products on soil microenvironment}

All Aflasafe products contain atoxigenic genotypes native to areas in which the products are used. Therefore, it is unlikely that applications of these products pose new or increased risks to non-target species in the soil. Registration of biopesticides based on atoxigenic VCGs in the US, Nigeria, Senegal, and Kenya waived conduct of toxicity tests against soil organisms because of the endemic nature of the active ingredients and because $A$. flavus is an extremely widely distributed species that has been known for over a hundred years and pathologies attributable to A. flavus are well described.

\section{Dynamics of Aspergillus genotypes}

Atoxigenic VCGs applied in biocontrol formulations dominate during the year of application and subsequently decline during the following years unless reapplied (Cotty and Mellon, 2006). The long-term fate of atoxigenic VCGs after sporulation during the year of application has been questioned (Ehrlich, 2014). The atoxigenic VCGs composing a biocontrol product will sporulate and then move to other substrates, including the target crop but with time only a portion of the applied VCGs will remain in the treated field while other portions will disperse to other areas, will be outcompeted by fungi arriving from neighbouring areas, or will lose viability. This will occur regardless of the inoculum delivery method (i.e. seed, bioplastic, or sclerotia based formulations). Applied atoxigenic VCGs should not be expected to remain indefinitely in the treated fields. In natural conditions, VCG community compositions are highly variable across years even when examining a single field or large agricultural areas (Bayman and Cotty, 1991; Ortega-Beltran, 2012; Ortega-Beltran et al., 2010). Thus, if community compositions of Aspergillus species are dynamic and continuously changing in natural conditions, it should be expected to observe similar dynamics when applying atoxigenic VCGs in biocontrol formulations and area-wide management strategies should be developed to retain and expand fungal communities with low average aflatoxinproducing potential throughout production areas.

\section{Recombination between atoxigenic and toxigenic VCGs in natural conditions}

During development of each Aflasafe product, the most common and widely distributed atoxigenic VCGs in a region are selected for use as biocontrol agents. Simple Sequence Repeat (SSR) data indicate that all these VCGs reproduce independently in a clonal manner; even when present in sympatric communities all SSR loci are in linkage disequilibrium. Within a VCG, all members of the VCG have identical alleles at each het locus (Bayman and Cotty, 1991; Leslie, 1993). Thus the association of specific SSR haplotypes with specific VCGs can only occur in a clonally (mitotically) reproducing fungus. Clonality and stability have been demonstrated in both toxigenic and atoxigenic VCGs (Grubisha and Cotty, 2010, 2015; Ortega-Beltran et al., 2016).

Distribution and frequency are taken as proxies for adaptation, competitiveness, and fitness in the target environments. Another criterion is the complete absence of toxigenic members in the selected atoxigenic VCGs (Atehnkeng et al., 2016). Critics of the use of atoxigenic A. flavus to reduce aflatoxin-producing fungi in crops have argued that a recombination event might result in highly competitive aflatoxin-producing progeny or 'superstrains' capable of producing a lot of aflatoxins (Ehrlich et al., 2015; Moore, 2015; Moore et al., 2013). However, aflatoxin production is not associated with virulence (Cotty, 1989). There is little variation in virulence among $A$. flavus genotypes (Mehl and Cotty, 2010, 2013) from which to select isolates with increased pathogenic aggression and increased competitiveness on a host is not associated with increased virulence (Mehl and Cotty, 2013; Mehl et al., 2012). Therefore, there are no high virulence traits to combine in order to form a new highly virulent aflatoxinproducing fungus.

Formation of functional sexual structures in A. flavus is uncommon and fastidious (Kwon-Chung and Sugui, 2009), although such structures have been observed (Horn et al., $2009,2014)$. Due to the presence of these structures, the possibility of genetic recombination has been suggested (Moore, 2015). The possibility of biocontrol VCGs acquiring the aflatoxin gene cluster through sexual reproduction when hyphae of competing strains physically touch each other during the infection process (Damman, 2015) has also been suggested. These structures and the genetic studies with them do not give definitive insight into the population genetics of $A$. flavus and movement of traits among individuals across generations. Fates of crosses after multiple generations is unknown and the large scale population genetics studies to date suggest there is little or no gene flow between VCGs (Grubisha and Cotty, 2010, 2015). Formation of low fertility sexual structures between pairings of fungi that have diverged for many thousands of years has been known for decades in other Ascomycete fungi, including Neurospora and Fusarium, two of the most intensively studied genera (Dettman et al., 2003; O'Donnell et al., 2004). These cases in Neurospora and Fusarium and the reported ability of some $A$. flavus isolates of alternate mating-type to undergo sexual reproduction may be primarily a remnant from an ancestral sexual cycle that has been largely lost in natural $A$. flavus populations (Geiser et al., 1996). Kwon-Chung and Sugui (2009) suggested that these laboratory sexual crosses might be considered 
demonstrations of a lack of fertility rather than proof of an active sexual cycle in nature. In case sexual reproduction occurs in nature in $A$. flavus, the impact of meiosis on biocontrol with atoxigenic VCGs of $A$. flavus could be very positive for aflatoxin mitigation allowing atoxigenicity to move into many other genetic backgrounds. This is because hybridisation between toxigenic and atoxigenic isolates of A. flavus in laboratory crosses was shown to produce progenies with either no aflatoxin-production or lower aflatoxin production than the aflatoxin-producing parent (Olarte et al., 2012). Although Olarte et al. (2012) suggest sexual recombination is common in A. flavus populations, including VCG YV36, to which AF36 belongs, after more than a decade of commercial use of AF36, dangerous recombinants have not been observed (Grubisha and Cotty, 2015). Farmers have used AF36 on more than a million hectares without adverse effect in Arizona, California, and Texas.

Abundant opportunity to exchange genetic material among VCGs has existed since VCG divergence. Application of native, widely distributed VCGs as biocontrol agents does not fundamentally change the opportunity for a rare recombination event. Atoxigenic VCGs are used as biopesticides in areas where the active ingredients are native and have co-evolved with both other VCGs in the A. flavus population and native host plants. Results to date demonstrate that the VCGs used as active ingredients have high genetic stability across vast areas (Adhikari et al., 2016; Grubisha and Cotty, 2015; Ortega-Beltran et al., 2016). As biocontrol programs to reduce aflatoxin contamination of crops are pursued globally, development of biopesticides based on atoxigenic $A$. flavus VCGs native to target agroecosystems need to be pursued. Aflasafe products are examples of this. These products contain only atoxigenic VCGs native to the target African nations and common in the target agroecosystems.

There is a misnomer that atoxigenicity is recent or rare or unstable. However, atoxigenic phenotypes are highly stable. This has been demonstrated over decades in agroecosystems experimentally (Grubisha and Cotty, 2015; Ortega-Beltran et al., 2016). Stability even extends over evolutionary time (Adhikari et al., 2016). Indeed, atoxigenic genotypes have persisted sufficiently long in VCGs that are biopesticide active ingredients that multiple mutations in the aflatoxin biosynthesis gene clusters have developed as the clusters degenerated after atoxigenicity arose (Adhikari et al., 2016). Clusters of the active ingredients of AF36, AflaGuard $^{\circledR}$, and the Nigerian Aflasafe product are illustrated for example in Figure 4.

\section{Conclusions}

Aflatoxin contamination of crops is common in warm production areas and is likely to increase with climate change. Use of biocontrol products with atoxigenic $A$. flavus active ingredients, is a proven method for reducing the aflatoxin content of crops. In the US, biopesticides based on atoxigenic $A$. flavus allow profitable crop production

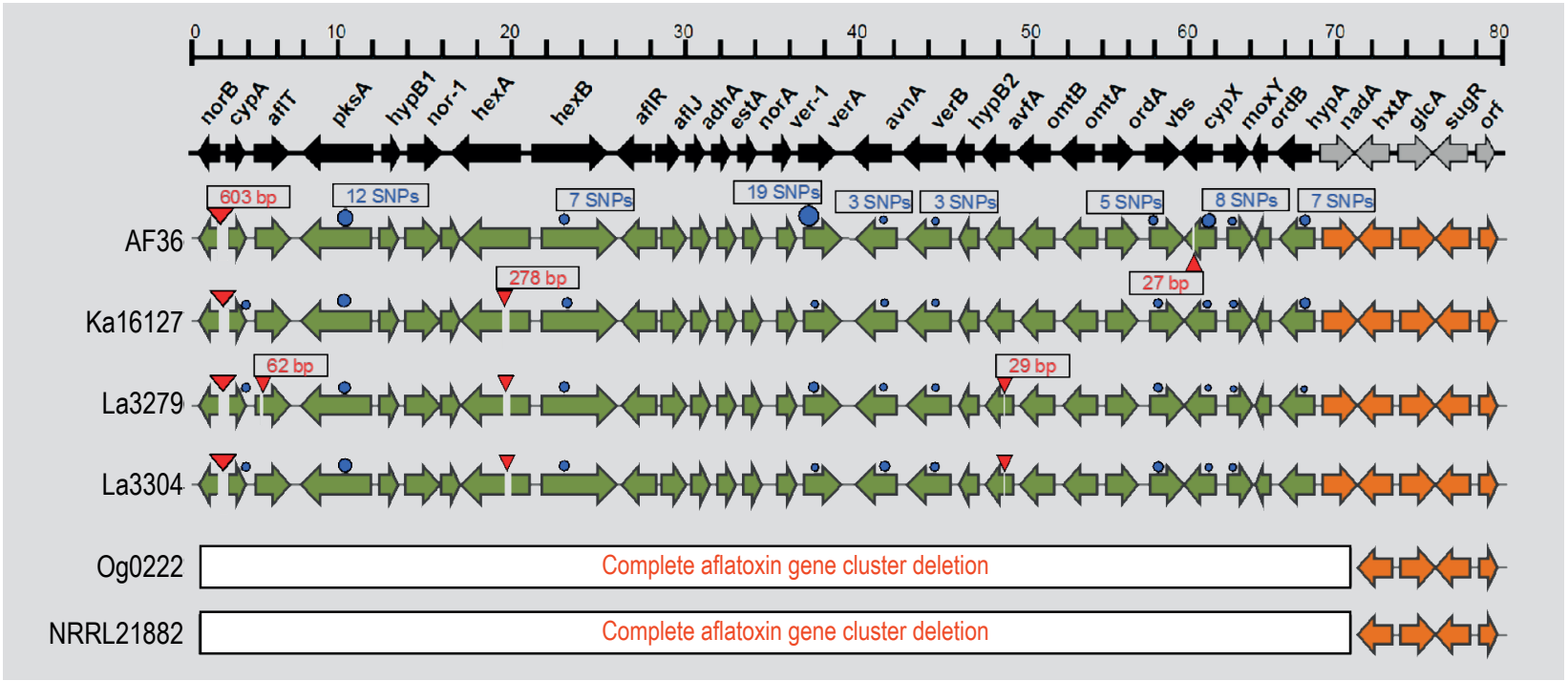

Figure 4. Lesions in aflatoxin gene clusters causing atoxigenicity for six Aspergillus flavus genotypes used as active ingredients in biocontrol products. Presence of multiple and diverse mechanisms of atoxigenicity in individual genotypes indicates persistence of atoxigenicity for the long periods required for continued cluster degeneration. Shown are the active ingredients of Aflasafe (Ka16127, La3279, La3304, and Og0222) from Nigeria, Aspergillus flavus AF36 (AF36) and Afla-Guard ${ }^{\circledR}$ (NRRL21882). Top is a schematic diagram of the cluster from an aflatoxin-producer. Numbers above or below red triangles indicate deletion size and above blue circles indicate non-synonymous single nucleotide polymorphisms (SNPs). Triangle and circle sizes are proportional to deletion size and SNP numbers, respectively. Data from Adhikari et al. (2016). 
in areas that had previously experienced frequent aflatoxin contamination. In sub-Saharan Africa, several biocontrol products have been developed under the name Aflasafe. Aflasafe products provide excellent protection from aflatoxin accumulation both before and after harvest and throughout the value chain. Biocontrol of aflatoxins is a cost-effective method for managing aflatoxins with the potential for a long-term solution to aflatoxin contamination in Africa (Bandyopadhyay and Cotty, 2013). However, for biocontrol to reach its full potential in relieving the burden of aflatoxin contamination in Africa, management programs that optimise both biocontrol's long-term and area-wide benefits are needed.

\section{Acknowledgements}

Parts of this study were funded by the following donors: Bill \& Melinda Gates Foundation (BMGF); the United States Agency for International Development (USAID); Bundesministerium für wirtschaftliche Zusammenarbeit und Entwicklung (BMZ, German Federal Ministry for Economic Cooperation and Development); AgResults (a collaborative initiative between the BMGF, the Department of Foreign Affairs and Trade of Australia (DFAT), the Department for International Development of the United Kingdom (DFID), Global Affairs Canada, and the USAID), MycoRed, CGIAR A4NH Research Program, CGIAR MAIZE Research Program, Meridian Institute on behalf of the Partnership for Aflatoxin Control in Africa (PACA), United States Department of Agriculture - Foreign Agricultural Service; Austrian Development Cooperation; and Commercial Agriculture Development Program of the Government of Nigeria.

\section{References}

Adhikari, B.N., Bandyopadhyay, R. and Cotty, P.J., 2016. Degeneration of aflatoxin gene clusters in Aspergillus flavus from Africa and North America. AMB Express 6: 62.

Alberts, J., Lilly, M., Rheeder, J., Burger, H., Shephard, G. and Gelderblom, W., in press. Technological and community-based methods to reduce mycotoxin exposure. Food Control. DOI: http:// doi.org/10.1016/j.foodcont.2016.05.029.

Atehnkeng, J., Donner, M., Ojiambo, P.S., Ikotun, B., Augusto, J., Cotty, P.J. and Bandyopadhyay, R., 2016. Environmental distribution and genetic diversity of vegetative compatibility groups determine biocontrol strategies to mitigate aflatoxin contamination of maize by Aspergillus flavus. Microbial Biotechnology 9: 75-88.

Atehnkeng, J., Ojiambo, P.S., Cotty, P.J. and Bandyopadhyay, R., 2014. Field efficacy of a mixture of atoxigenic Aspergillus flavus Link: Fr vegetative compatibility groups in preventing aflatoxin contamination in maize (Zea mays L.). Biological Control 72: 62-70.

Atehnkeng, J., Ojiambo, P.S., Ikotun, T., Sikora, R.A., Cotty, P.J. and Bandyopadhyay, R., 2008. Evaluation of atoxigenic isolates of Aspergillus flavus as potential biocontrol agents for aflatoxin in maize. Food Additives and Contaminants Part A 25: 1266-1273.
Bandyopadhyay, R. and Cotty, P.J., 2013. Biological controls for aflatoxin reduction. In: Unnevehr, L. and Grace, D. (eds.) Aflatoxins: finding solutions for improved food safety. IFPRI, Washington, DC, USA, pp. 44-45.

Bandyopadhyay, R., Kumar, M. and Leslie, J.F., 2007. Relative severity of aflatoxin contamination of cereal crops in West Africa. Food Additives and Contaminants 24: 1109-1114.

Battilani, P., Toscano, P., Van der Fels-Klerx, H., Moretti, A., Camardo Leggieri, M., Brera, C., Rortais, A., Goumperis, T. and Robinson, T., 2016. Aflatoxin $B_{1}$ contamination in maize in Europe increases due to climate change. Scientific Reports 6: 24328.

Bayman, P. and Cotty, P.J., 1991. Vegetative compatibility and genetic diversity in the Aspergillus flavus population of a single field. Canadian Journal of Botany 69: 1707-1711.

Bhat, R., Rai, R.V. and Karim, A., 2010. Mycotoxins in food and feed: present status and future concerns. Comprehensive Reviews in Food Science and Food Safety 9: 57-81.

Bock, C.H., Mackey, B. and Cotty, P.J., 2004. Population dynamics of Aspergillus flavus in the air of an intensive cultivated region of south-west Arizona. Plant Pathology 53: 422-433.

Brown, R.L., Menkir, A., Chen, Z.-Y., Bhatnagar, D., Yu, J., Yao, H. and Cleveland, T.E., 2013. Breeding aflatoxin-resistant maize lines using recent advances in technologies - a review. Food Additives and Contaminants Part A 30: 1382-1391.

Camardo-Leggieri, M. Bertuzzi, T., Pietri, A. and Battilani, P., 2015. Mycotoxin occurrence in maize produced in Northern Italy over the years 2009-2011: focus on the role of crop related factors. Phytopathologia Mediterranea 54: 212.221.

Cardwell, K.F. and Cotty, P.J., 2002. Distribution of Aspergillus section Flavi among field soils from the four agroecological zones of the republic of Bénin, West Africa. Plant Disease 79: 1039-1045.

Council for Agricultural Science and Technology (CAST), 2003. Mycotoxins: risks in plant, animal and human systems. Task force report No. 139. Ames, IA, USA.

Centers for Disease Control and Prevention (CDC). 2004. Outbreak of aflatoxin poisoning - eastern and central provinces, Kenya, JanuaryJuly 2004. Morbidity and Mortality Weekly Report 53: 790-793.

Chan-Hon-Tong, A., Charles, M.-A., Forhan, A., Heude, B. and Sirot, V., 2013. Exposure to food contaminants during pregnancy. Science of the Total Environment 458: 27-35.

Chandler, D., Bailey, A.S., Tatchell, G.M., Davidson, G., Greaves, J. and Grant, W.P., 2011. The development, regulation and use of biopesticides for integrated pest management. Phylosophical Transactions of the Royal Society B 367: 1987-1998.

Conrath, U., Beckers, G.J., Flors, V., García-Agustín, P., Jakab, G., Mauch, F., Newman, M.-A., Pieterse, C.M., Poinssot, B. and Pozo, M.J., 2006. Priming: getting ready for battle. Molecular PlantMicrobe Interactions 19: 1062-1071.

Cotty, P.J., 1989. Virulence and cultural characteristics of two Aspergillus flavus strains pathogenic on cotton. Phytopathology 79: 808-814.

Cotty, P.J., 1997. Aflatoxin-producing potential of communities of Aspergillus section Flavi from cotton producing areas in the United States. Mycological Research 11: 698-704. 
Cotty, P.J., 2001. Cottonseed losses and mycotoxins. In: Kirkpatrick, T.L. and Rothrock, C.S. (eds.) Compendium of cotton diseases. Part 1. APS Press, St. paul, MN, USA, pp. 9-13.

Cotty, P.J., 2006. Biocompetitive exclusion of toxigenic fungi. In: Barug, D., Bhatnagar, D., Van Egdmond, H.P., Van der Kamp, J.W., Van Osenbruggen, W.A. and Visconti, A. (eds.) The mycotoxin factbook. Wageningen Academic Publishers, Wageningen, the Netherlands, pp. 179-197.

Cotty, P.J., Antilla, L. and Wakelyn, P.J., 2007. Competitive exclusion of aflatoxin producers: Farmer driven research and development. In: Vincent, C., Goettel, N. and Lazarovits, G. (eds.) Biological control: a global perspective. CAB International, Wallingford, UK, pp. 242-253.

Cotty, P.J., Bayman, P., Egel, D.S. and Elias, K.S., 1994. Agriculture, aflatoxins and Aspergillus. In: Powell, K. (ed.) The genus Aspergillus. Plenum Press, New York, NY, USA, pp. 1-27.

Cotty, P.J. and Cardwell, K.F., 1999. Divergence of West African and North American communities of Aspergillus section Flavi. Applied and Environmental Microbiology 65: 2264-2266.

Cotty, P.J. and Jaime-Garcia, R., 2007. Influences of climate on aflatoxin-producing fungi and aflatoxin contamination. International Journal of Food Microbiology 119: 109-115.

Cotty, P.J. and Mellon, J.E., 2006. Ecology of aflatoxin-producing fungi and biocontrol of aflatoxin contamination. Mycotoxin Research 22: 110-117.

Cotty, P.J., Probst, C. and Jaime-Garcia, R., 2008. Etiology and management of aflatoxin contamination. In: Leslie, J.F., Bandyopadhyay, R. and Visconti, A. (eds.) Mycotoxins: detection methods, management, public health, and agricultural trade. CAB International, Wallingford, UK, pp. 287-299.

Damann Jr., K.E., 2015. Atoxigenic Aspergillus flavus biological control of aflatoxin contamination: what is the mechanism? World Mycotoxin Journal 8: 235-244.

Dettman, J.R., Jacobson, D.J., Turner, E., Pringle, A. and Taylor, J.W., 2003. Reproductive isolation and phylogenetic divergence in Neurospora: comparing methods of species recognition in a model eukaryote. Evolution 57: 2721-2741.

Dicko, M.H., Gruppen, H., Traoré, A.S., Voragen, A.G. and Van Berkel, W.J., 2006. Sorghum grain as human food in Africa: relevance of starch content and amylase activities. African Journal of Biotechnology 5: 384-395.

Diedhiou, P.M., Bandyopadhyay, R., Atehnkeng, J. and Ojiambo, P.S., 2011. Aspergillus colonization and aflatoxin contamination of maize and sesame kernels in two agro-ecological zones in Senegal. Journal of Phytopathology 159: 268-275.

Donner, M., Atehnkeng, J., Sikora, R.A., Bandyopadhyay, R. and Cotty, P.J., 2009. Distribution of Aspergillus section Flavi in soils of maize fields in three agroecological zones of Nigeria. Soil Biology and Biochemistry 41: 37-44.

Donner, M., Atehnkeng, J., Sikora, R.A., Bandyopadhyay, R. and Cotty, P.J., 2010. Molecular characterization of atoxigenic strains for biological control of aflatoxins in Nigeria. Food Additives and Contaminants Part A 27: 576-590.

Dorner, J.W., 2004. Biological control of aflatoxin contamination of crops. Journal of Toxicology-Toxin Reviews 23: 425-450.
Dorner, J.W., 2009. Biological control of aflatoxin contamination in corn using a nontoxigenic strain of Aspergillus flavus. Journal of Food Protection 72: 801-804.

Dorner, J.W. and Lamb, M.C., 2006. Development and commercial use of Afla-Guard ${ }^{\oplus}$, an aflatoxin biocontrol agent. Mycotoxin Research 22: 33-38.

Doster, M.A., Cotty, P.J. and Michailides, T.J., 2014. Evaluation of the atoxigenic Aspergillus flavus strain AF36 in pistachio orchards. Plant Disease 98: 948-956.

Ehrlich, K.C., 2014. Non-aflatoxigenic Aspergillus flavus to prevent aflatoxin contamination in crops: advantages and limitations. Frontiers in Microbiology 5: 50.

Ehrlich, K.C., Moore, G.G., Mellon, J.E. and Bhatnagar, D., 2015. Challenges facing the biological control strategy for eliminating aflatoxin contamination. World Mycotoxin Journal 8: 225-233.

Food and Agricultural Organization of the United Nations (FAO), 2016. FAOSTAT. Available at: http://faostat.fao.org.

Fountain, J.C., Khera, P., Yang, L., Nayak, S.N., Scully, B.T., Lee, R.D., Chen, Z.-Y., Kemerait, R.C., Varshney, R.K. and Guo, B., 2015. Resistance to Aspergillus flavus in maize and peanut: Molecular biology, breeding, environmental stress, and future perspectives. The Crop Journal 3: 229-237.

Geiser, D.M., Timberlake, W.E. and Arnold, M.L., 1996. Loss of meiosis in Aspergillus. Molecular Biology and Evolution 13: 809-817.

Ghassemi-Golezani, K., Chadordooz-Jeddi, A., Nasrullahzadeh, S. and Moghaddam, M., 2010. Influence of hydro-priming duration on field performance of pinto bean (Phaseolus vulgaris L.) cultivars. African Journal of Agricultural Research 5: 893-897.

Gong, Y., Egal, S., Hounsa, A., Turner, P., Hall, A., Cardwell, K. and Wild, C., 2003. Determinants of aflatoxin exposure in young children from Benin and Togo, West Africa: the critical role of weaning. International Journal of Epidemiology 32: 556-562.

Grace, D., Mahuku, G., Hoffmann, V., Atherstone, C., Upadhyaya, H.D. and Bandyopadhyay, R., 2015. International agricultural research to reduce food risks: case studies on aflatoxins. Food Security 7: 569-582.

Grubisha, L.C. and Cotty, P.J., 2010. Genetic isolation among sympatric vegetative compatibility groups of the aflatoxin-producing fungus Aspergillus flavus. Molecular Ecology 19: 269-280.

Grubisha, L.C. and Cotty, P.J., 2015. Genetic analysis of the Aspergillus flavus vegetative compatibility group to which a biological control agent that limits aflatoxin contamination in USA crops belongs. Applied and Environmental Microbiology 81: 5889-5899.

Heise, H., Crisan, A. and Theuvsen, L., 2015. The poultry market in Nigeria: market structures and potential for investment in the market. International Food and Agribusiness Management Review 18 Special Issue A: 197-222.

Hell, K., Cardwell, K.F. and Poehling, H.-M., 2003. Relationship between management practices, fungal infection and aflatoxin for stored maize in Benin. Journal of Phytopathology 153: 690-698.

Hell, K., Cardwell, K.F., Setamou, M. and Poehling, H.-M., 2000. The influence of storage practices on aflatoxin contamination in maize in four agroecological zones of Benin, west Africa. Journal of Stored Products Research 36: 365-382. 
Hell, K., Fandohan, P., Bandyopadhyay, R., Kiewnick, S., Sikora, R. and Cotty, P.J., 2008. Pre-and post-harvest management of aflatoxin in maize: an African perspective. In: Leslie, J.F., Bandyopadhyay, R. and Visconti, A. (eds.) Mycotoxins: detection methods, management, public health, and agricultural trade. CAB International, Wallingford, UK, pp. 219-229.

Hernandez-Vargas, H., Castelino, J., Silver, M.J., Dominguez-Salas, P., Cros, M.-P., Durand, G., Le Calvez-Kelm, F., Prentice, A.M., Wild, C.P. and Moore, S.E., 2015. Exposure to aflatoxin $B_{1}$ in utero is associated with DNA methylation in white blood cells of infants in The Gambia. International Journal of Epidemiology 4: 1238-1248.

Horn, B.W. and Greene, R.L., 1995. Vegetative compatibility within populations of Aspergillus flavus, A. parasiticus, and A. tamarii from a peanut field. Mycologia 87: 324-332.

Horn, B.W., Ramirez-Prado, J.H. and Carbone, I., 2009. Sexual reproduction and recombination in the aflatoxin-producing fungus Aspergillus parasiticus. Fungal Genetics and Biology 46: 169-175.

Horn, B.W., Sorensen, R.B., Lamb, M.C., Sobolev, V.S., Olarte, R.A., Worthington, C.J. and Carbone, I., 2014. Sexual reproduction in Aspergillus flavus sclerotia naturally produced in corn. Phytopathology 104: 75-85.

International Agency for Research on Cancer (IARC), 2002. Aflatoxins. In: Monograph on the evaluation of carcinogenic risks to humans. Vol. 82. Some traditional herbal medicines, some mycotoxins, naphthalene and styrene. IARC, Lyon, France, pp. 171-300.

Jaime-Garcia, R. and Cotty, P.J., 2004. Aspergillus flavus in soils and corncobs in South Texas: Implications for management of aflatoxins in corn-cotton rotations. Plant Disease 88: 1366-1371.

Jaime-Garcia, R. and Cotty, P.J., 2010. Crop rotation and soil temperature influence the communitiy structure of Aspergillus flavus in soil. Soil Biology and Biochemistry 42: 1842-1847.

Jisha, K., Vijayakumari, K. and Puthur, J.T., 2013. Seed priming for abiotic stress tolerance: an overview. Acta Physiologiae Plantarum 35: 1381-1396.

Joffe, A.Z., 1969. Aflatoxin produced by 1626 isolates of Aspergillus flavus from groundnut kernels and soils in Israel. Nature 221: 492. Jones, R.K., 1987. The influence of cultural practices on minimizing the development of aflatoxin in field maize. In: Zuber, M.S., Lillehoj, E.B. and Renfro, B.L. (eds.) Aflatoxin in maize: a proceedings of the workshop. CIMMYT, Mexico, D.F., Mexico, pp. 136-144.

Kaur, S., Gupta, A.K. and Kaur, N., 2002. Effect of osmo-and hydropriming of chickpea seeds on seedling growth and carbohydrate metabolism under water deficit stress. Plant Growth Regulation 37: 17-22.

Kilman, S., 1993. Food-safety strategy pits germ vs. germ. The Wall Street Journal 1993: B2.

Klich, M.A., 2007. Aspergillus flavus: the major producer of aflatoxin. Molecular Plant Pathology 8: 713-722.

Kos, J., Mastilović, J., Hajnal, E.J. and Šarić, B., 2013. Natural occurrence of aflatoxins in maize harvested in Serbia during 2009-2012. Food Control 34: 31-34.

Kwon-Chung, J.K. and Sugui, J.A., 2009. Sexual reproduction in Aspergillus species of medical and economical importance: why so fastidious? Trends in Microbiology 17: 481-487.
Lamplugh, S., Hendrickse, R., Apeagyei, F. and Mwanmut, D., 1988. Aflatoxins in breast milk, neonatal cord blood, and serum of pregnant women. British Medical Journal 296: 968.

Latgé, J.-P., 1999. Aspergillus fumigatus and aspergillosis. Clinical Microbiology Reviews 12: 310-350.

Leslie, J.F., 1993. Fungal vegetative compatibility. Annual Review of Phytopathology 31: 127-150.

Lillehoj, E.B., Kwolek, F.W., Horner, E.S., Widstrom, N.W., Josephson, L.M., Franz, A.O. and Catalano, E.A., 1980. Aflatoxin contamination of preharvest corn: role of Aspergillus flavus inoculum and insect damage. Cereal Chemistry 57: 255-257.

Liu, Y. and Wu, F., 2010. Global burden of aflatoxin-induced hepatocellular carcinoma: a risk assessment. Environmental Health Perspectives 118: 818-824.

Magan, N., Medina, A. and Aldred, D., 2011. Possible climatechange effects on mycotoxin contamination of food crops pre- and postharvest. Plant Pathology 60: 150-163.

Matacic, C., 2016. Fungal toxins are poisoning Africa's children, says new report. Science. DOI: https://doi.org/10.1126/science.aaf4085.

Matumba, L., Van Poucke, C., Njumbe Ediage, E., Jacobs, B. and De Saeger, S., 2015. Effectiveness of hand sorting, flotation/washing, dehulling and combinations thereof on the decontamination of mycotoxin-contaminated white maize. Food Additives and Contaminants: Part A 32: 960-969.

Mehl, H.L. and Cotty, P.J., 2013. Influence of plant host species on intraspecific competition during infection by Aspergillus flavus. Plant Pathology 62: 1310-1318.

Mehl, H.L. and Cotty, P.J., 2010. Variation in competitive ability among isolates of Aspergillus flavus from different vegetative compatibility groups during maize infection. Phytopathology 100: 150-159.

Mehl, H.L., Jaime, R., Callicott, K.A., Probst, C., Garber, N.P., OrtegaBeltran, A., Grubisha, L.C. and Cotty, P.J., 2012. Aspergillus flavus diversity on crops and in the environment can be exploited to reduce aflatoxin exposure and improve health. Annals of the New York Academy of Sciences 1273: 7-17.

Moore, G.G., Mack, B.M. and Beltz, S.B., 2013. Testing the efficacy of eGFP-transformed Aspergillus flavus as biocontrol strains. Food and Nutrition Sciences 4: 469-479.

Moore, G.G., 2015. Heritability study of eGFP-transformed Aspergillus flavus strains. World Mycotoxin Journal 8: 301-310.

O’Donnell, K., Ward, T.J., Geiser, D.M., Kistler, H.C. and Aoki, T., 2004. Genealogical concordance between the mating type locus and seven other nuclear genes supports formal recognition of nine phylogenetically distinct species within the Fusarium graminearum clade. Fungal Genetics and Biology 41: 600-623.

Okike, I., Samireddypalle, A., Kaptoge, L., Fauquet, C., Atehnkeng, J., Bandyopadhyay, R., Kulakow, P., Duncan, A., Alabi, T. and Blummel, M., 2015. Technical innovations for small-scale producers and households to process wet cassava peels into high quality animal feed ingredients and Aflasafe ${ }^{\text {rm }}$ substrate. Food Chain 5: 71-90.

Olarte, R.A., Horn, B.W., Dorner, J.W., Monacell, J.T., Singh, R., Stone, E.A. and Carbone, I., 2012. Effect of sexual recombination on population diversity in aflatoxin production by Aspergillus flavus and evidence for cryptic heterokaryosis. Molecular Ecology 21: 1453-1476. 
Oluwafemi, F. and Ibeh, I.N., 2011. Microbial contamination of seven major weaning foods in Nigeria. Journal of Health, Population and Nutrition: 415-419.

Ortega-Beltran, A., 2012. Ecology, distribution, toxigenicity and diversity of aflatoxin-producing fungal communities in maize fields of Mexico and interactions of these fungi with native maize landraces. PhD dissertation, University of Arizona, Tucson, AZ, USA. Available at: http://hdl.handle.net/10150/265833.

Ortega-Beltran, A., Grubisha, L.C. and Cotty, P.J., 2010. Genetic diversity within a vegetative compatibility group of aflatoxinproducing fungi. Phytopathology 101: S250.

Ortega-Beltran, A., Grubisha, L.C., Callicott, K.A. and Cotty, P.J., 2016. The vegetative compatibility group to which the US biocontrol agent Aspergillus flavus AF36 belongs is also endemic to Mexico. Journal of Applied Microbiology 120: 986-998.

Orum, T.V., Bigelow, D.M., Nelson, M.R., Howell, D.R. and Cotty, P.J., 1997. Spatial and temporal patterns of Aspergillus flavus strain composition and propagule density in Yuma County, Arizona, soils. Plant Disease 81: 911-916.

Paterson, R.R.M. and Lima, N., 2010. How will climate change affect mycotoxins in food? Food Research International 43: 1902-1914.

Pelletier, M. and Reizner, J., 1992. Comparison of fluorescence sorting and color sorting for the removal of aflatoxin from large groups of peanuts. Peanut Science 19: 15-20.

Perrone, G., Haidukowski, M., Stea, G., Epifani, F., Bandyopadhyay, R., Leslie, J.F. and Logrieco, A., 2014. Population structure and Aflatoxin production by Aspergillus Sect. Flavi from maize in Nigeria and Ghana. Food Microbiology 41: 52-59.

Pildain, M.B., Frisvad, J.C., Vaamonde, G., Cabral, D., Varga, J. and Samson, R.A., 2008. Two novel aflatoxin-producing Aspergillus species from Argentinean peanuts. International Journal of Systematic and Evolutionary Microbiology 58: 725-735.

Probst, C., Bandyopadhyay, R. and Cotty, P.J., 2014. Diversity of aflatoxin-producing fungi and their impact on food safety in sub-Saharan Africa. International Journal of Food Microbiology 174: 113-122.

Probst, C., Bandyopadhyay, R., Price, L.E. and Cotty, P.J., 2011. Identification of atoxigenic Aspergillus flavus isolates to reduce aflatoxin contamination of maize in Kenya. Plant Disease 95: 212-218.

Probst, C., Callicott, K.A. and Cotty, P.J., 2012. Deadly strains of Kenyan Aspergillus are distinct from other aflatoxin producers. European Journal of Plant Pathology 132: 419-429.

Probst, C., Njapau, H. and Cotty, P.J., 2007. Outbreak of an acute aflatoxicosis in Kenya in 2004: Identification of the causal agent. Applied and Environmental Microbiology 73: 2762-2764.

Reynolds, J.F., Smith, D.M.S., Lambin, E.F., Turner, B., Mortimore, M., Batterbury, S.P., Downing, T.E., Dowlatabadi, H., Fernández, R.J. and Herrick, J.E., 2007. Global desertification: building a science for dryland development. Science 316: 847-851.

Russell, T.E., Watson, T.F. and Ryan, G.F., 1976. Field accumulation of aflatoxin in cottonseed is influenced by irrigation termination dates and pink bollworm infestation. Applied and Environmental Microbiology 31: 711-713.
Shephard, G.S., 2003. Aflatoxin and food safety: recent African perspectives. Journal of Toxicology: Toxin Reviews 22: 267-286.

Shephard, G.S., 2008. Risk assessment of aflatoxins in food in Africa. Food Additives and Contaminants Part A 25: 1246-1256.

Simberloff, D. and Stiling, P., 1996. Risks of species introduced for biological control. Biological Conservation 78: 185-192.

Smith, R., 2011a. Corn and wheat lead NE Texas crop options for 2012. Southwest Farm Press, available at: http://tinyurl.com/j3y7cf2.

Smith, R., 2011b. Nov. 1 good target date to plant NE Texas wheat. Southwest Farm Press, available at: http://tinyurl.com/hh4z8fc.

Taylor, A. and Harman, G., 1990. Concepts and technologies of selected seed treatments. Annual Review of Phytopathology 28: 321-339.

United States Environmental Protection Agency (US-EPA), 2003. Biopesticide Registration Action Document Aspergillus flavus AF36. Available at: http://tinyurl.com/gmnqmqk.

United States Environmental Protection Agency (US-EPA), 2004. Biopesticide Registration Action Document Aspergillus flavus NRRL21882. Available at: http://tinyurl.com/zs9fjgz

Waliyar, F., Osiru, M., Ntare, B., Kumar, K., Sudini, H., Traore, A. and Diarra, B., 2015. Post-harvest management of aflatoxin contamination in groundnut. World Mycotoxin Journal 8: 245-252.

Wang, Z., Liu, Z. and Wei, Y., 2003. Effects of super absorbent polymers coating on photosynthesis and water use efficiency of soybean. Agricultural Research in the Arid Areas 22: 105-108.

Wheeler, T. and Von Braun, J., 2013. Climate change impacts on global food security. Science 341: 508-513.

Widstrom, N.W., 1979. The role of insects and other plant pests in aflatoxin contamination of corn, cotton and peanuts - a review. Journal of Environmental Quality 8: 5-11.

Wild, C., Miller, J.D. and Groopman, J.D., 2016. Mycotoxin control in low-and middle-income countries. IARC Working Group Report No. 9. World Health Organization, Geneva, Switzerland.

Williams, J.H., Phillips, T.D., Jolly, P.E., Stiles, J.K., Jolly, C.M. and Aggarwal, D., 2004. Human aflatoxicosis in developing countries: a review of toxicology, exposure, potential health consequences, and interventions. American Journal of Clinical Nutrition 80: 1106-1122.

Williams, W.P., 2006. Breeding for resistance to aflatoxin accumulation in maize. Mycotoxin Research 22: 27-32.

Wilson, D.M. and Payne, G.A., 1994. Factors affecting Aspergillus flavus group infection and aflatoxin contamination of crops. In: Eaton, D.L. and Groopman, J.D. (eds.) The toxicology of aflatoxins. Human health, veterinary, and agricultural significance. Academic Press, San Diego, CA, USA, pp. 309-329.

Wu, F. and Khlangwiset, P., 2010. Health economic impacts and costeffectiveness of aflatoxin-reduction strategies in Africa: case studies in biocontrol and post-harvest interventions. Food Additives \& Contaminants: Part A 27: 496-509.

Yang, L., Yang, Y., Chen, Z., Guo, C. and Li, S., 2014. Influence of super absorbent polymer on soil water retention, seed germination and plant survivals for rocky slopes eco-engineering. Ecological Engineering 62: 27-32. 
